\title{
The role of dietary nitrate and the oral microbiome on blood pressure and vascular tone
}

Article

Accepted Version

Alzahrani, H. S., Jackson, K. G. ORCID:

https://orcid.org/0000-0002-0070-3203, Hobbs, D. A. and Lovegrove, J. A. (2021) The role of dietary nitrate and the oral microbiome on blood pressure and vascular tone. Nutrition Research Reviews, 34 (2). pp. 222-239. ISSN 0954-4224 doi: https://doi.org/10.1017/S0954422420000281 Available at https://centaur.reading.ac.uk/94686/

It is advisable to refer to the publisher's version if you intend to cite from the work. See Guidance on citing.

To link to this article DOI: http://dx.doi.org/10.1017/S0954422420000281

Publisher: Cambridge University Press

All outputs in CentAUR are protected by Intellectual Property Rights law, including copyright law. Copyright and IPR is retained by the creators or other copyright holders. Terms and conditions for use of this material are defined in the End User Agreement. 


\section{CentAUR}

Central Archive at the University of Reading

Reading's research outputs online 
2 Alzahrani H.S. ${ }^{1,2}$, Jackson K.G. ${ }^{1}$, Hobbs D.A. ${ }^{1}$ and Lovegrove J.A. ${ }^{1}$

$3{ }^{1}$ Hugh Sinclair Unit of Human Nutrition, Department of Food and Nutritional Sciences, University

4 of Reading, Reading RG6 6AP, UK

$5 \quad{ }^{2}$ Department of Food Science and Nutrition, King Saud University, P. O. BOX 2454, Riyadh

6 11451, Saudi Arabia

7

8 Disclaimer: There are no conflicts of interest.

9

10 HA is supported by a PhD studentship funded by King Saud University (Saudi Arabia)

12 Address correspondence to Prof JA Lovegrove, Hugh Sinclair Unit of Human Nutrition,

13 Department of Food \& Nutritional Sciences, University of Reading, Reading, RG6 6AP, United

14 Kingdom. Telephone: +44 (0)118 3786418; Fax: +44 (0)118 3787708; Email:

15 j.a.lovegrove@ reading.ac.uk

16

17 Running title: Dietary nitrate, oral bacteria and vascular tone 


\section{Abstract:}

19 There is increasing evidence for the health benefits of dietary nitrates including lowering blood pressure and enhancing cardiovascular health. Although commensal oral bacteria play an important

21 role in converting dietary nitrate to nitrite, very little is known about the potential role of these bacteria in blood pressure regulation and maintenance of vascular tone. The main purpose of this review is to present the current evidence on the involvement of the oral microbiome in mediating the beneficial effects of dietary nitrate on vascular function and to identify sources of inter and intra-individual differences in bacterial composition. A systematic approach was used to identify the relevant articles published on PubMed and Web of Science in English from January 1950 until September 2019 examining the effects of dietary nitrate on oral microbiome composition and association with blood pressure and vascular tone. To date, only a limited number of studies have been conducted, with $n=9$ in humans and $n=3$ in animals focusing mainly on blood pressure. In general, elimination of oral bacteria with use of a chlorhexidine based antiseptic mouthwash reduced the conversion of nitrate to nitrite and was accompanied in some studies by an increase in blood pressure in normotensive subjects. In conclusion, our findings suggest that oral bacteria may play an important role in mediating the beneficial effects of nitrate-rich foods on blood pressure. Further human intervention studies assessing the potential effects of dietary nitrate on oral bacteria composition and relationship to real time measures of vascular function are needed, particularly in individuals with hypertension and those at risk of developing cardiovascular diseases.

Key words:

41 Nitrate, nitrite, nitric oxide, oral microbiome, blood pressure, mouthwash, 


\section{Introduction}

Cardiovascular diseases (CVDs), including coronary heart disease and stroke, are one of the leading causes of death globally. In 2017, the World Health Organization (WHO) reported that 18 million people had died from CVDs worldwide which represents $31 \%$ of deaths ${ }^{1}$. Abnormally raised blood pressure, defined as greater than 140 (systolic)/90 (diastolic) $\mathrm{mmHg}$, is an independent risk factor for CVDs and this silent killer is associated with a three-fold higher risk of having a stroke or developing heart failure ${ }^{2,3}$. High blood pressure affects more than 1 in 4 adults in England, around 12.5 million people. However, the prevalence of hypertension appears to differ between sexes, with $31 \%$ reported amongst men and 26\% amongst women ${ }^{4}$. Dysfunction of the endothelium, which controls vascular tone and strongly associated with hypertension, is now recognised as an early, but potentially reversible, step in the development of $\mathrm{CVDs}^{5}$.

The control of vascular function is known to be influenced by dietary factors, with nitraterich vegetables considered an important modulator ${ }^{6,7,8}$. This has been demonstrated in many observational and cohort studies which have shown consumption of nitrate and nitrite-rich foods to significantly improve cardiovascular health ${ }^{9}$ such as lowering blood pressure ${ }^{10}$ in both healthy ${ }^{11}$ and hypertensive individuals $^{12}$, reducing endothelial dysfunction ${ }^{13,14} 15,16,17$ and inflammation ${ }^{18}$, protection from ischemia reperfusion injury ${ }^{19}$, and improved exercise performance in patients with heart failure ${ }^{20}$. A prospective cohort study has also concluded that an increased adherence to a diet high in nitrate is accompanied by a significant reduction in the risk of suffering both cardiovascular complications and death due to any cause ${ }^{21}$. Clinically, nitrate supplementation or use of nitrate as a medication to increase the bioavailability of nitrite and nitric oxide (NO) can reduce blood pressure $^{22}$. The interest in using dietary nitrates as a treatment for lowering blood pressure is growing but mechanisms underlying the effects are unclear which limits their current application as a dietary treatment for hypertension ${ }^{22}$. Furthermore, there is some evidence to suggest that high dietary nitrate intakes are associated with negative effects on health, which has led to the development of the Acceptable Daily Intake (ADI) for nitrate of $3.7 \mathrm{mg} / \mathrm{kg}$ body weight/day and for 
nitrite of $0.07 \mathrm{mg} / \mathrm{kg}$ body weight/day ${ }^{23}$. The ADI for nitrate is based on the risk of methaemoglobinaemia commonly known as blue baby syndrome, which can occur following high nitrate intake in some babies, and can be fatal ${ }^{24}$. In addition, some epidemiological studies have reported an association between dietary nitrite intake and colorectal cancer. However, the weight of evidence only supports a significant relationship between cancer and red and processed meat ${ }^{25}$, with little known about vegetables and drinking water. The nitrate and nitrite within processed meat may be a contributing factor in the association with cancer, although this needs further confirmation. Humans are naturally colonised by an array of microorganisms, such as commensal or symbiotic communities, whose metabolic activity is important for host physiology and health. Commensal oral bacteria and those residing in the gastrointestinal (GI) tract play an important role in converting dietary nitrate to nitrite and the potent vasodilator $\mathrm{NO}^{26,27,28,29,30,31}$. Up to $85 \%$ of ingested nitrate is reduced to nitrite by the nitrate-reducing bacteria in the oral cavity ${ }^{32}$ raising the salivary nitrite concentration to 1000 times that of plasma $^{28}$. A cohort study conducted in 281 volunteers found that the high abundance of nitrate reducing bacteria was associated with blood pressure in normotensive individuals, although this association was not found in those with hypertension ${ }^{33}$. To date, very little is known about the role of these oral bacteria in the control of vascular function, and the variation in composition that exists between individuals. The aim of this review is to present the current evidence on the potential role of dietary nitrate and the oral microbiome on vascular function including blood pressure and vascular tone. Important determinants of the number and composition of the oral bacteria will also be described. However, the impact of dietary nitrate interventions on vascular function only will not be specifically addressed in this instance due to the large number of review articles which already exist in this research area ${ }^{13,14} 15,16,17$. Before presentation of the methodology and results of the literature review, we provide a general overview of dietary nitrate sources, the pathways for the conversion of dietary nitrate and nitrite to NO, location and type of nitrate-reducing bacteria in the oral cavity and their potential role in regulating vascular tone. 
97 Nitrate, nitrite and nitric oxide sources and nitric oxide pathway

98 NO, the most effective form of nitrate, was first recognised in 1998 as an important signalling 99 molecule in the cardiovascular system ${ }^{34}$. NO plays a significant role in virtually all organs in the

100 body, and higher circulating concentrations are associated with a lower CVD risk ${ }^{35}$. In additional to 101 the dietary (exogenous) sources of nitrate and nitrite which leads to the production of nitrite, and 102 subsequently NO, via the oral bacteria, the body can also derive NO endogenously (figure1). The 103 endogenous pathway can occur in a number of different tissues in the body using three forms of NO 104 synthase (NOS) enzyme, neuronal (nNOS), endothelial (eNOS) and inducible NOS (iNOS). eNOS 105 was initially discovered in endothelial cells and is important in modulating vascular tone and 106 upholding endothelial integrity. However, eNOS can also be expressed in various tissues and 107 requires the presence of oxygen, calcium and calmodulin to be activated ${ }^{36}$. Within the endothelium, 108 L-arginine undergoes a 5-electron oxygen dependent oxidation to produce NO and L-citrulline, 109 catalysed by the synthase enzymes. Five cofactors required by the NOS enzymes are flavin adenine 110 dinucleotide (FAD), flavin mononucleotide (FMN), tetrahydrobiopterin (BH4), reduced

111 nicotinamide-adenine dinucleotide phosphate (NADPH) and heme iron ${ }^{28}$. Once produced in the 112 endothelial cell, NO rapidly diffuses to the underlying smooth muscle layer where it mediates blood 113 vessel vasodilation. Any NO remaining in the circulation is rapidly converted to nitrate by 114 oxyhaemoglobin or superoxide before it enters the enterosalivary pathway. Therefore, the NO 115 produced has a relatively short half-life in the order of seconds to minutes ${ }^{37}$.

\section{Nitrate metabolism, enterosalivary circulation and gastrointestinal tract}

118 High levels of inorganic nitrate are found in vegetables (such as beetroot and spinach) as well as 119 drinking water, and these dietary sources accounts for $80 \%$ of the daily intake. In contrast, the 120 intake of dietary nitrite is very low, being approximately 100 times lower $^{38}$ than that of nitrate ${ }^{39}$. 121 Although the process of re-circulation of nitrates in the body has been known since 1970s, the 
122 importance of the oral nitrate-reducing bacteria in the enterosalivary circulation has only recently

123 been recognised ${ }^{27}$ (Figure 2). The key role these bacteria play in nitrate reduction was supported by

124 a previous human study in which a significant correlation was found between high abundance of

125 oral nitrate-reducing bacteria and nitrite level in saliva ${ }^{40}$. Nitrate secretion from the salivary glands

126 leads to a 10 fold rise in salivary nitrate levels ${ }^{41}$ and this nitrate enriched saliva appears to be a

127 supportive environment for the growth of the oral bacteria particularly the nitrate-reducing bacteria

128 on the tongue ${ }^{42}$. These bacteria are mostly facultative anaerobes which use nitrate as an alternative

129 electron acceptor for their respiration ${ }^{43}$. A symbiotic relationship therefore exists between the oral

130 commensal bacteria in which they receive nitrate from the host for their own respiration and in

131 return produce nitrites required by the host $\mathrm{t}^{42}$. This relationship is particularly important for nitrite

132 bioavailability since humans are unable to complete this process independent of the nitrate-reducing

133 bacteria, with $80 \%$ of nitrates swallowed and present in the stomach produced by the oral

134 commensals ${ }^{44}$. Once in the stomach, contact with the gastric acidity leads to the protonation of

135 nitrites to form nitrous acid $\left(\mathrm{HNO}_{2}\right)$, which then decomposes into not only $\mathrm{NO}$ but also several

136 other nitrogen oxides ${ }^{45}$ which have localised benefits on maintaining the gastric mucosa layer ${ }^{46}$ and

137 enhancing mucosal blood flow ${ }^{45}$ which increases the thickness of the mucosal layer ${ }^{47}$. This process

138 is referred to as non-enzymatic conversion which does not require bacteria. However, the presence

139 of Helicobacter pylori can contribute to a more acidic environment within the stomach and increase

140 non-enzymatic conversion ${ }^{48}$. Residual nitrates and nitrites are then absorbed in the small intestine

141 with the half-life of circulating nitrate in the blood stream of around 5-6 hours ${ }^{49}$. In contrast, plasma

142 nitrite concentrations start to increase within 15 minutes of nitrate ingestion and reach a peak level

143 in 2 hours $^{50}$. A large portion, approximately $70-75 \%$ of the plasma nitrate, is excreted in the urine

144 whereas the remaining $25 \%$ is stored in the salivary gland and then recycled in the enterosalivary

145 pathway ${ }^{51}$.

The role of the nitrate-reducing bacteria can persist past the oral cavity as most of these

147 bacteria move into the stomach with both swallowed food and saliva. Limited studies have 
investigated the existence of these bacteria in the stomach and have confirmed that the gastric

149 acidity is not a germ-free environment ${ }^{52}$. Although the gastric $\mathrm{pH}$ is below 5 , some bacteria species

150 can tolerate the stomach acidity, with a culture based study reporting Clostridium spp,

151 Veillonella spp and Lactobacillus spp as the most predominant gastric species ${ }^{53}$, with

152 Veillonella spp identified as the most abundant nitrate reducing bacteria ${ }^{43}$. There are many factors

153 that can influence gastric acidity such as inflammation and long-term use of proton pump inhibitors.

154 The $\mathrm{pH}$ level has been found to have a positive impact on nitrate and nitrite concentration in the

155 gastric juice. In a study conducted in 99 patents with dyspepsia, results showed that when the $\mathrm{pH}$

156 level of gastric mucosal surface increased there was a comparable increase in both nitrate and nitrite concentrations. Findings from another study conducted in participants with achlorhydria, in which gastric pH ranged from 6-8, reported three genera of nitrate reducing bacteria: Streptococci and Neisseriae to be responsible for the nitrite accumulation in the gastric secretions ${ }^{54}$.

The small intestine and colon contain many different species of bacteria including both

161 facultative and obligate anaerobes which are involved in the bioconversion of nitrite to NO, although they are not necessarily the same as the nitrate reducing bacteria found in the oral cavity ${ }^{55}$. A study conducted in germ-free and normal rats has shown that NO can be produced by the bacteria resident in the small intestine of normal rats, but not in germ free rats ${ }^{56}$. Furthermore, two studies have identified Lactobacilli, Bifidobacteria ${ }^{56}$, Escherichia coli and Shigella as the predominant nitrate reducing bacteria in the large intestine ${ }^{57}$. However, an in-vitro study which used pure strains of gut bacteria incubated in agar media with nitrate then nitrite, found that in the presence of nitrite, both Bifidobacterial and Lactobacilli generated large amounts of NO, up to 5000 parts per billion 169 (ppb), but only approximately $35 \mathrm{ppb}$ of nitrate ${ }^{58}$. Interestingly, Sobko et al reported that the NO 170 formed was being utilised by Escherichia coli and Staphylococcus aureus ${ }^{46}$. These authors 171 speculated that these gut bacteria may consume NO in order to help adapt to their environment in this in vitro experiment. Therefore, it appears that the presence of NO and other nitrate metabolites 173 in the large intestine may be dependent on the relevant abundance of these bacteria species and their 
production and utilisation of $\mathrm{NO}^{59}$. Localised effects of the NO could include altering blood flow which could potentially increase the uptake of nitrate and nitrite in the proximal small intestine where the majority are absorbed ${ }^{44}$. However, the NO level in the GI tract could also be influenced by other factors such as $\mathrm{pH}$ level, inflammation, oxygen tension and the level of dietary nitrate intake of an individual. Further studies are need to determine the direct effects of nitrate and nitrite on gut bacteria composition and nitrate metabolism.

\section{Bacterial nitrate reduction in the oral cavity, composition and location}

A continuous flow of saliva, specialized mucosal surfaces and teeth in the human oral cavity provide a unique microbial habitat for bacteria. Most of these bacteria are found on the dorsum (surface) of the tongue and around the teeth where a wash of $1 \mathrm{ml}$ of saliva can contain up to $10^{7}-$ $10^{8}$ microorganisms ${ }^{44}$. However, only 700 species have currently been identified ${ }^{44}$. The majority of these bacteria shelter in the gingival crevices between teeth which represents a conducive anaerobic environment. Here, the gingival crevicular fluid bathes the bacteria within a nutritionally rich medium supporting their proliferation ${ }^{60}$. In contrast, the smoother surfaces of teeth have much lower levels of bacteria due to the forces that act on these areas during eating and drinking. However, the nitrate-reducing bacteria are found predominately on the rear dorsum of tongue, with a higher proportion of gram-negative bacteria found within the papillae of the tongue compared to the surface. Some studies have identified the genus and species of these bacteria that can produce nitrate reductases and nitrite reductases that aid in the production of nitric oxides. These include: Veillonella atypical Veillonella dispar, Actinomyces eslumdii, A. odontolyticus, Staphylococcus epidermids, Neisseria flarescens, Haemophilus, Porphyromonas, Rothia mucilaginosa, Rothia dentocarisa, Prevotella and Leptotrichia ${ }^{42,43}$. The two major groups of oral nitrate-reducing bacteria are the strict anaerobes such as Veillonella atypica and Veillonella dispar and the facultative anaerobes such as Actinomyces odontolyticus and Rothia mucilaginosa ${ }^{42}$. Facultative anaerobes are mostly prevalent on the surface of the tongue, with a study stratifying participants 
according to oral nitrate reduction capacity observing a higher abundance of Streptococcus,

201 Granulicatella, Prevotella, Neisseria, and Haemophilus on the posterior surface of the tongue 202 compared to Actinomyces $^{43}$. Interestingly, although lower in prevalence, Actinomyces have been 203 reported to be more efficient reducers of dietary nitrates under anaerobic conditions.

\section{Mechanisms by which bacteria may convert nitrate to nitrite}

The three mechanisms through which nitrates are converted to nitrites and other components by bacteria are denitrification, assimilation and dissimilation. The first process, denitrification, occurs in the oral cavity under aerobic conditions ${ }^{61}$ and is also called the respiratory nitrate reduction process. During microbial respiration, oxygen is replaced by nitrogen oxides as terminal electron acceptors and ultimately reduces nitrate to nitrous oxide or free nitrogen ${ }^{62}$. Most of the bacteria

211 which have genes for respiratory nitrate reductases (nirS and nirK) prefer aerobic conditions ${ }^{63}$ such 212 as Rothia spp and Neisseriae spp. However, some denitrification species of bacteria also reside in 213 anaerobic conditions ${ }^{44}$ such as Veillonella. The specialised surface of the tongue dorsum therefore 214 represents a microaerophilic environment which allows denitrification to occur under both aerobic 215 and anaerobic conditions. In the oral cavity, nitrite $\left(\mathrm{NO}_{2}\right)$ is initially formed from salivary nitrate $216\left(\mathrm{NO}_{3}\right)$ by some oral bacteria such as Actinomyces ${ }^{43}$ that are considered to possess the nitrate 217 reductase enzyme (nar) and further converts nitrite to NO through either enzymatic (nir) or non218 enzymatic denitrification. The latter process is a well-established step in the gastric environment of 219 the stomach. NO is then converted to nitrous oxide $\left(\mathrm{N}_{2} \mathrm{O}\right)$ by nitric oxide reductase (nor) and finally 220 to nitrogen $\left(\mathrm{N}_{2}\right)$ by nitrous oxide reductase (nos). The nitrogen oxides and enzymes that participate 221 in the process of denitrification are as follows:

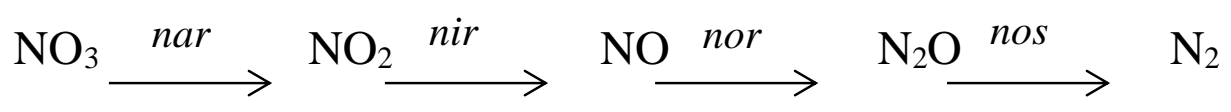


In the second pathway known as dissimilation, nitrate is reduced to ammonia $\left(\mathrm{NH}_{4}+\right)$ by periplasmic nitrate reductase (nap), with the intermediate product being nitrite ${ }^{64}$. This two-step process is strictly anaerobic and occurs in the human gut by the facultative anaerobes ${ }^{55}$.

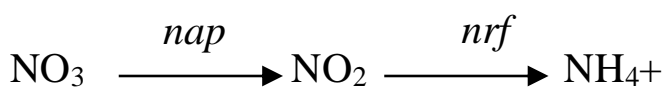

Assimilation, which occurs predominantly in plants, water and soil ${ }^{65}$, is the third pathway. Similar to denitrification, the conversion of nitrate to ammonia occurs but during this pathway, the enzyme cytoplasmic nitrate reductase (nas) is used ${ }^{65}$. In this biosynthetic anabolic pathway, nitrite is further reduced to ammonia, which can then undergo ammonium assimilation by incorporating the amino acid glutamine ${ }^{44}$. The assimilation and dissimilation processes are therefore important in the utilization of nitrates. Nitrifying bacteria (including Nitrobacter, Nitrococcus and Nitrosomonas) ${ }^{66}$ are responsible for the dissimilation and ammonification of nitrates and oxidises ammonium salts and nitrites to nitrates in a process called nitrification. It has been hypothesised that this process might happen in the gut, but to date, this has not been described ${ }^{67}$.

In humans, nitrate reduction seems to occur either directly, such as in assimilatory nitrate reduction, or during a series of reactions during respiratory nitrate reduction. Notably, the latter process needs more than one enzyme for further reduction which is mediated by the bacterial communities $^{44}$. This suggests that nitrate reducing capacity of nitrate-reducing bacteria is related to the bacterial species, cellular location of enzymes and environmental conditions such as oxygen level. Therefore, dissimulation would occur more in the gut and denitrification in the oral cavity ${ }^{67}$. Although the role of oral bacteria in mediating the beneficial effect of nitrate on vascular function is poorly understood, this review aims to address this knowledge gap by focussing on studies that used antibacterial mouthwash and toothpaste to determine the importance of the presence of oral microbiome on blood pressure and vascular tone. 


\section{Methods}

252 A systematic approach was used to identify the relevant human and animal studies which investigated 253 the role of dietary nitrate and the oral microbiome on blood pressure. PubMed and Web of Science were used for the literature search which included all relevant articles published in English from January 1950 until September 2019. There were three stages in the selection process. The combinations of the key terms used in the search strategy were as follows: ("Nitrate" OR "Nitrite" OR "Nitric Oxide”) AND (“Oral Bacteria” OR "Oral Microbiom” OR "Nitrate-Reducing Bacteria”) AND ("Blood Pressure" OR "Hypertension" OR "Cardiovascular" OR "Vascular Function") AND (“Mouth Wash" OR “Antiseptic” OR “Antibacterial”). The titles and abstracts of the identified papers were screened by one member of the review team (HA) who identified potentially relevant papers. This review was restricted to animal studies and human studies which used antibacterial mouthwash or toothpaste to determine the effects on oral nitrate reduction on blood pressure and vascular tone. Only published peer-reviewed literature was considered and 'grey' literature such as dissertations, conference proceedings, reports, letters to editors and other non-peer-reviewed research, was excluded. After duplicates were removed, the abstract and full papers were screened for eligibility. In addition, a hand-search of the bibliographies of the articles found from the electronic database searches was also conducted. An overview of the literature search is shown in Figure 3.

The quality of the included human RCTs and animal studies were assessed for the risk of bias using the Cochrane risk of bias tool ${ }^{68}$ for human studies and SYRCLE's tool ${ }^{69}$ for animal studies.

\section{Results and Discussion}

273 The systematic search identified 160 publications. Of these, 11 relevant publications were included, with 9 describing studies conducted in humans and 3 in animals. The risk of bias assessment summaries for each study are presented in Supplementary Tables 1 and 2, respectively. Animal studies will be discussed before studies including human participants. This will be followed by 
discussion of the non-modifiable and modifiable factors affecting intra-individual variability in number and composition of oral bacteria, with potential mechanisms of action.

\section{Animal studies}

Of the 14 animal studies which have investigated the effect of nitrate on blood pressure, only 3 studies have determined whether oral bacteria are important in mediating the improvements in blood pressure and endothelial function (Table 2). Formation of bioactive NO takes place within the gastric environment of the stomach as a result of the enterosalivary circulation of nitrate, as well as systemically in the blood vessels. In 2009 , Petersson and his colleagues ${ }^{70}$ reported daily mouthwash treatment for 7 days in rats to attenuate both the gastroprotection provided by NO and the diastolic blood pressure lowering effect of sodium nitrate. A similar pattern was also evident for the mean arterial pressure in the rats treated with mouthwash and nitrate, but the lack of an effect in the rats treated with mouthwash and nitrite suggested that oral bacteria play an important role in the metabolism of nitrate to NO and mediated vasodilation. Furthermore, these rats also had reduced oral bacteria suggesting that nitrite could bypass the reduction step by the oral bacteria and was being reduced in the circulation or within endothelial cells to NO, or via effects on the formation of the intermediate nitrosothiols ${ }^{70}$. However, dietary nitrite intake is generally lower than that of nitrate, and the half-life in plasma shorter (seconds versus hours) which suggests that even if nitrite directly stimulates NO signalling, the quantity and kinetics of nitrite versus nitrate indicates that the critical aspect of this mechanism is the reduction of nitrate. Therefore, the role that dietary nitrite plays in blood pressure lowering may be more limited relative to nitrate.

In agreement, Hyde et al $^{29}$ also reported a significant reduction in diastolic blood pressure and increase in plasma nitrite concentrations following the addition of sodium nitrate to drinking water in male Wistar rats. However, in this study, mouthwash treatment was unable to diminish the blood pressure lowering effects of the nitrate supplementation. The authors speculated that the direct application of the chlorhexidine-based mouthwash (Vedco, St. Joseph, MO) to the tongue 
surface using a swab might not have enabled sufficient time for the mouthwash to exert its full extent on the bacteria relative to mouthspray ${ }^{29}$. A novel aspect of this longer-term supplementation study was the focus on the changes in the microbiota composition on the rat tongue in response to the treatments. Compared with baseline, there was a greater relative abundance of nitrate reducing bacteria (Haemophilus spp and Steptococcus spp) after 6 days of sodium nitrate consumption, and of these Haemophilus parainfluenzae has also been identified as 1 of 14 species contributing to nitrate reduction in the oral cavity of healthy adults. Co-supplementation of mouthwash with nitrate was found to increase the diversity of the oral bacteria present relative to nitrate intake only, with increases found in the low abundance taxa such as Enterobacteriaceae, Corynebacterium, and Morganella. Therefore, the use of mouthwash appeared to disturb the oral microbiome by reducing the abundance of the normally dominant taxa but not completely to impact nitrate reduction. These findings suggest that the lower abundance taxa which were evident after mouthwash treatment may be functionally important in the bioactivation of dietary nitrate. However, the authors did caution against translating these findings on the oral bacteria composition to humans since the oral human microbiome has been shown to be more diverse and of a differing composition compared with the $\operatorname{rat}^{29}$

The impact of mouthwash on chronic changes in blood pressure in response to nitrate or nitrite supplementation was further examined by Pinheiro et $\mathrm{al}^{71}$ in both control and hypertensive rats. After 4 weeks, significant reductions in mean arterial pressure and systolic blood pressure were evident in both the nitrate and nitrite groups, with concordant increases found in circulating plasma nitrate and nitrite levels. Interestingly, co-supplementation with mouthwash attenuated the rise in plasma nitrite levels by $25-30 \%$ in both groups but was only found to blunt the blood pressure lowering effect of nitrate, with little impact found on blood pressure in the mouthwash and nitrite group. In agreement with Petersson et $\mathrm{al}^{70}$, these findings suggested that anti-hypertensive effects of nitrite were potentially occurring via non-enzymatic reactions within the gastric environment after swallowing this ion independently of the enterosalivary pathway and potentially via non-enzymatic 
reactions within the gastric environment after swallowing this anion. Analysis of the endogenously produced vasodilatory compound S-nitrosothiol and levels of vascular nitrosylation revealed mouthwash to reduce nitrosylation responses to nitrate only, leading the authors to speculate that Snitrosylation was an important mediator of the blood pressure lowering effects of both nitrate and nitrite $^{70,71}$. Studies have also reported that the foods consumed with dietary nitrites, such as conjugated fatty acids, are also a target of nitrating species in the stomach leading to the formation of nitro-fatty acids (such as nitro-conjugated linoleic acid). These electrophiles have been shown to have anti-hypertensive effects independent of S-nitrosothiols suggesting that they may also play a role in mediating the effects of nitrate and nitrite on blood pressure ${ }^{72}$. Antiseptic mouthwash was proposed to attenuate the beneficial effects of dietary nitrate intake on blood pressure by reducing the amount of nitrite formation by the oral bacteria and therefore reaching the stomach, inhibiting gastric formation of S-nitrosothiols. However, the positive benefits on blood pressure of raised Snitrosothiols was only found in the antihypertensive rats, supporting previous observations in both animals and humans that raised blood pressures often show a greater sensitivity to the antihypertensive effects of medication and/or dietary modification.

Studies performed in animals may provide useful insights into the mechanisms underlying the effects of oral bacteria in the bioactivation of nitrate. However, findings in rats and mice need to be interpreted with caution due to differences in physiology and dependence on nitrate as a source of NO between organisms. In contrast to humans, rats and mice do not recirculate nitrate in saliva ${ }^{73}$ and so salivary nitrate concentrations never exceed those levels found in plasma ${ }^{74}$ and they also have other nitrate reducing mechanisms that may work in tandem with nitrate reduction by the oral bacteria to control nitrite and NO level ${ }^{73}$.

\section{Human Studies}

The publications describing the human studies were divided into those which examined 1) the association between oral bacteria with nitrate/nitrite levels and/or blood pressure ( $n=5$; Table 2$)$ and 
2) the combined effects of nitrate ingestion and oral bacteria on nitrate/nitrite levels and/or blood pressure ( $n=4$; Table 3). The role of the oral bacteria in mediating systemic nitrite production after nitrate intake has been primarily investigated with the use of an antiseptic mouthwash to remove the bacteria prior to the measurement of the outcomes of interest. The type of mouthwash has been shown to be important, with the strong antibacterial chlorhexidine-based mouthwash (Corsodyl) found to be more effective at reducing Veillonella dispar (nitrate reducing bacteria) in the oral cavity than Listerine (mixture of essential oils), Isodine and Cepacol (antibacterial) in healthy adults $^{75}$. In support of these findings, gargling with $10 \mathrm{ml}$ of chlorohexidine mouthwash (Corsodyl) twice for 1 min was also found to reduce the bacterial count of nitrate reducing bacteria by approximately $80 \%$ and virtually abolish the oral nitrate reducing capacity compared with no mouthwash in healthy subjects ${ }^{27}$. Although nitrate accumulated in saliva after ingestion of sodium nitrate in both studies, a significant reduction in the conversion of salivary nitrate to nitrite after mouthwash was associated with 30\% lower plasma nitrate concentrations at $3 \mathrm{~h}$ post-ingestion, compared with no prior use of mouthwash. In contrast, a randomised cross-over study found an antibacterial toothpaste to have no effect on salivary or plasma nitrate concentrations in 16 women after consuming $400 \mathrm{mg}$ of nitrate before brushing their teeth with antibacterial toothpaste $(0.3 \%$ triclosan) or toothpaste containing no antibacterial agent ${ }^{76}$. The lack of an effect observed with the antibacterial toothpaste may reflect either the lower prevalence of the nitrate reducing bacteria on 373 the surface of the teeth, relative to the tongue, or the less efficient removal of the bacteria sheltering within the gingival crevices between the teeth compared with mouthwash. Four studies have determined the impact of mouthwash on changes in oral nitrate reducing capacity and blood pressure (Table 2). Compared with no mouthwash, Kapil et al ${ }^{41}$ reported that using $0.2 \%$ chlorhexidine twice daily for 7 days significantly increased systolic and diastolic blood pressure measured using 3 different techniques (clinic, ambulatory and home measurements) by approximately 3 and $2 \mathrm{mmHg}$ respectively in 19 healthy normotensive subjects. Interestingly, the effects of mouthwash treatment on blood pressure was evident after only a single use of the 
chlorhexidine mouthwash and was maintained for the following 6 days. The rise in blood pressure was significantly correlated with the significant reduction in plasma nitrite levels, with only a trend 383 for a relationship with the salivary nitrite, highlighting the potential importance of the oral nitratereducing bacteria in blood pressure modulation.

In 15 subjects treated with anti-hypertensive medication, the attenuation found in oral nitrate reducing capacity after daily use of chlorhexidine mouthwash for 3 days was associated with an increase in systolic blood pressure of $2.3 \mathrm{mmHg}$, but only a trend for a decrease in plasma nitrite concentrations compared with the control (tap water) ${ }^{77}$. The lack of a significant effect on the plasma nitrite response relative to Kapil et $\mathrm{al}^{41}$ was thought to be due to the study visit being performed $12 \mathrm{~h}$ after prior use of the mouthwash treatment or related to the age or medication use of the hypertensive participants. In order to determine the mechanism underlying the effects of dietary nitrate intake on blood pressure, plasma cGMP, a mediator of NO-dependant smooth muscle relaxation in the endothelium and a good marker of NO production, can be measured. Although increases in plasma nitrite and cGMP after dietary nitrate intake have been previously associated with blood pressure lowering, no effects were evident on cGMP concentrations after 3 days of using mouthwash. This may be related to the lack of a nitrate challenge on the study visit (which provides an important source of NO under hypoxic conditions) but could also suggest that dietary nitrate may impact on vascular tone via direct effects on smooth muscle function.

In contrast to these two studies, Tribble et al ${ }^{78}$ reported use of chlorhexidine mouthwash twice daily for 7 days to be associated with a highly variable effect on clinic systolic blood pressure (an increase of at least $5 \mathrm{mmHg}$ found in $\mathrm{n}=9$ subjects whereas a decrease was observed in $\mathrm{n}=4$ ) in an orally healthy cohort. Post-hoc data analysis revealed the inclusion of tongue cleaning as part of the daily dental hygiene routine to play a significant role in the responses observed both on blood pressure and the diversity of the oral bacteria at baseline and during the study. Specifically, regular tongue cleaning was associated with a greater ability to reduce nitrite to NO whereas the lack of tongue cleaning resulted in an oral microbiome composition which favoured conversion of nitrite to 
ammonia and not NO. The authors speculated the use of chlorhexidine mouthwash was having a chemo-stimulatory effect on the oral bacteria, with the temporary loss of bacterial numbers proposed to stimulate a rapid population recovery and increase in bacterial nitrate reductase activity. However, these effects may also reflect a protective upregulation of the nitrate, nitrite and NO regulating mechanisms in the microbiota suddenly detached from their biofilms during tongue cleaning and warrants further investigation.

In a cross-over study, treatment with chlorhexidine $(0.2 \%)$ for 3 days was shown to have no effect on clinic or $24 \mathrm{~h}$ ambulatory blood pressure in 17 young females compared with a placebo mouthwash ${ }^{79}$. Although a reduction in salivary nitrite and oral nitrate reducing capacity was found after the antibacterial mouthwash, comparable changes were not evident in either the plasma or urine samples collected. The lack of effects observed relative to other studies may reflect the short intervention time with the mouthwash treatments or inclusion of female participants only. Based on a previous study conducted by the same research group in athletes, they speculated that cross-talk may exist between the enterosalivary nitrate-nitrite-NO pathway and eNOS, with a greater intake of dietary nitrate associated with a lower eNOS activity. However, whether a reduction in nitratenitrite-NO with antibacterial mouthwash leads to an upregulation in eNOS is yet to be established.

In the studies presented in Table 3, measures of blood pressure have been related to salivary and plasma nitrate/nitrite levels following nitrate intake and use of mouthwash. In agreement with previous findings, Woessner et al $^{30}$ found antibacterial mouthwashes to attenuate postprandial salivary and plasma nitrite concentrations following dietary nitrate intake (concentrated beetroot juice) compared with the weaker antiseptic mouthwash and control. Although changes in clinic systolic blood pressure 0-3 h after the treatments were not related to plasma/salivary nitrite or nitrate levels, systolic blood pressure at $4 \mathrm{~h}$ was 2-5 mmHg higher after Chlorhexidine and Cepacol mouthwashes compared with control and Listerine mouthwash. These findings potentially suggest an important role of the nitrate-nitrite-NO enterosalivary pathway, but should be interpreted with caution due to the small sample size, inclusion of male subjects only and the short duration of the 
study visit relative to the expected peak in plasma nitrite concentrations (approximately $3 \mathrm{~h}$ ).

434 Furthermore, these findings may have been influenced by the large inter-individual variability 435 observed in blood pressure responses following the mouthwash treatments. In the study of McDonagh and co-workers ${ }^{80}$, consumption of $2 \times 70 \mathrm{ml}$ shots of concentrated beetroot juice and daily use of strong or weak antibacterial mouthwash for 6 days were 438 found to have limited effects on baseline blood pressure and salivary and plasma nitrate/nitrite 439 levels compared with the control (water). However, differences were evident 2-4 h after drinking 440 the beetroot juice, with the rise in plasma nitrite found to be attenuated after use of the strong and 441 weak mouthwash for 6 days. These changes were associated with a reduced oral nitrate reducing 442 capacity after the strong mouthwash, with lower nitrite levels compared with both the weak and 443 placebo mouthwashes. Although changes in resting measures of blood pressure (supine and seated) 444 and pulse wave analysis (arterial stiffness) after the juice were not influenced by the streng th of the 445 mouthwash used, differences were evident in blood pressure during low-intensity activity on the 446 treadmill. In particular, there was a greater increase in systolic blood pressure and mean arterial 447 pressure after rinsing with the strong (Chlorhexidine) compared with the control (water) 448 mouthwash. The lack of effect on arterial stiffness even in the presence of lower salivary and 449 plasma nitrite levels after the strong mouthwash indicates that either the availability of NO was not 450 altered sufficiently over the $4 \mathrm{~h}$ acute test period in these young active participants or that their 451 higher physical active level may have masked any effects of the mouthwash on the vascular 452 function measures. However, this is one of the only studies to incorporate a measure of blood vessel 453 elasticity to determine the role of oral bacteria in mediating the beneficial effects of beetroot juice 454 on vascular function, and so further studies are needed in which to compare these findings and 455 determine the underlying mechanisms. As highlighted in the human studies, oral bacteria composition appears to vary between 457 individuals, with both non-modifiable (e.g. age, sex, genetics and tongue physiology) and 458 modifiable (e.g. diet, health conditions, life style and dental hygiene routine) factors considered to 
impact on the abundance and prevalence of nitrate reducing bacteria in the oral cavity. These factors

460 are important to consider during interpretation of the study findings and for informing the design of

461 future studies exploring the role of oral nitrate reducing bacteria on the regulation of vascular

462 function. The following section summarises the main factors identified from the human studies.

\section{Intra-individual variability in number and composition of oral bacteria}

466 Geographical location and culture have all been suggested to impact on oral bacteria composition.

467 Findings from a study including participants from Northern and Southern Europe, reported a higher

468 abundance of Rothia and unclassified Gemellaceae in Finnish populations compare to Spanish

469 while Lactococcus, Fusobacterium and Porphyromonas genus were significantly higher in Spanish

470 compare to Finnish groups ${ }^{81}$. Comparing findings of this study with another study which

471 investigated the differences in oral bacteria between people living in Africa, Alaska and Germany

472 showed that oral bacteria composition is highly variable between countries ${ }^{82}$. These differences may

473 represent the sex and age distributions of these different populations, genetic make-up and habitual

474 food preferences ${ }^{83}, 82$.

Moreover, the dorsal surface of the tongue plays a major role in nitrate reduction and represents a highly papillated surface area. The papillary structure of the human tongue is unique in nature and supports a higher bacterial density than the mucosal surface, accumulating oral debris

478 and anaerobic bacteria on the rear of tongue ${ }^{42}$. There are three kinds of papillae on the tongue:

479 fungiform, circumvallate and foliate papillae. The fungiform papillae have a mushroom shape and 480 are found predominately on the dorsal surface of the tongue covering up to two-thirds of the 481 surface. Their shape supports a higher bacterial density ${ }^{84}$. However, the shape and number of 482 papillae varies between individuals which has been related to differences in oral bacteria 483 composition. Studies have shown that a number of factors can affect the papillary number on the 
tongue including ageing (with lower number of papillae observed in those individuals over 60 years), genetic make-up, ethnicity ${ }^{81}$, demographics and environment ${ }^{84}$.

Within the oral cavity, the presence of teeth increases the bacterial density compared to those with permanent tooth loss since the gingival crevices between teeth represent a greater surface area and environment for bacterial growth ${ }^{85}$. Other important factors considered to impact on the variety of nitrate reduction bacteria present in the oral cavity are ageing and sex. However, in a recent human study conducted in $n=9$ participants $<22$ years and $n=9>70$ years, a similar salivary microbiome at baseline and after placebo beetroot juice was found in both groups. Comparable changes in bacterial composition (increases in Rothia and Neisseria) were also evident in both age groups in response to consuming $70 \mathrm{ml}$ of beetroot juice $(\approx 6.2 \mathrm{mmol}$ nitrate $)$ daily for 10 days ${ }^{86}$ suggesting that age was not an important modulator of the oral bacteria composition in this study. Few studies have determined differences in oral bacteria composition between men and women. In order to address this knowledge gap, Kapil and colleagues ${ }^{87}$ examined the impact of sex on nitrate reducing bacteria abundance in 13 male and 13 females age 18-45 years. Oral bacteria samples were collected before and after nitrate supplementation and all samples were analyzed by $16 \mathrm{~S}$ rRNA sequencing. Significant sex dependent effects on oral nitrate reducing bacteria composition were not found in this study. However, sub-group analysis indicated females to have a non-significant tendency for a higher activity of nitrate reducing bacteria than $\operatorname{men}^{87,74}$ but these findings need to be confirmed in a suitably powered study.

\section{Modifiable factors}

Several modifiable factors have been reported to influence and change the oral nitrate reducing bacteria composition, with dietary nitrate intake considered to be one of the most important factors $^{27,88}$. In a recent cross-over study conducted in 18 volunteers assigned to receive a nitrate supplement or a placebo for 10 days, an increase in the abundance of some nitrate reducing bacteria, particularly Rothia and Neisseria was linked with the ability of an individual to reduce the nitrate 
supplement. However, changes were not observed with the Prevotella and Veillonella species ${ }^{86}$.

511 Interestingly, these results corroborate findings from another study which reported the reduction in

512 Prevotella and Veillonella species in the oral cavity of elderly adults following dietary nitrate intake

513 to be associated with a lower mortality risk in this population ${ }^{88}$. Furthermore, the increased

514 prevalence of Rothia and Neisseria species relative to the Prevotella and Veillonella species was

515 linked to higher NO bioavailability in both saliva and plasma ${ }^{86}$. These findings imply that the oral

516 bacteria community is responsive to changes in the level of dietary nitrate intake ${ }^{89}$. However, the

517 authors also reported that individuals with a higher abundance of Campylobacter concisus and

518 Prevotella melaninogenica in their oral cavity at baseline may not be as responsive to dietary nitrate

519 intake than those with a lower proportion of these bacteria ${ }^{86}$. This might reflect the fact that both

520 Campylobacter. concisus and Prevotella. melaninogenica are predominately nitrite, but not nitrate,

521 reducers in the oral cavity. Therefore, dietary nitrate availability may affect the growth and

522 composition of particular groups of oral bacteria which can be related to improved cardiovascular

523 health ${ }^{89}$. Of particular note, drinking beetroot juice rich in dietary nitrate can increase the oral cavity

$524 \mathrm{pH}$ from 7.0 to 7.5 which is close to the optimal $\mathrm{pH}$ of 8 required for nitrate reductase activity ${ }^{90}$.

525 Therefore, the effect of $\mathrm{pH}$ is also important in terms of the proliferation and inhibition of different

526 populations within the oral bacterial community ${ }^{86}$.

In a similar fashion, some health conditions have also been reported to influence the oral

528 bacterial composition, with a lower density of nitrate reducing bacteria and a different bacterial

529 composition found in people with raised blood pressure (hypertensives) than normotensive

530 subjects $^{31}$. A recent novel study has provided further evidence on the relationship between

531 differences in oral bacteria composition with hypertension in postmenopausal women $(\mathrm{n}=446)$. This

532 study analysed oral bacterial samples by using 16S RNA sequencing and found that the abundance

533 of Prevotella oral species 317 and Streptococcus oralis were significantly lower in women with

534 elevated blood pressure compared with those with normal blood pressure ${ }^{91}$. Furthermore, the

535 differences in the oral bacteria communities between groups also seemed to be associated with the 
severity and progression of the hypertension ${ }^{33}$. Conversely, a higher abundance of nitrate reducing bacteria were observed in individuals who suffer from migraines (a vascular driven process associated with changes in NO). Interestingly, the dominant nitrate reducing bacteria in these individuals were Pseudomonas and Streptococcus which are not common in subjects who did not suffer with migraines. Oligotyping (the technique for differentiation between closely related microbial taxa) ${ }^{92}$ was performed for both genera to investigate the strain-level differences across the bacterial population. Pseudomonas decompose to 2 oligotypes (different strains of the same species) and has differential abundance patterns with significantly higher abundance in oligotype 2 in those suffering from migraines compared with non-sufferers ${ }^{93}$. These results suggest that the type of these oral bacteria may be more prevalent in people with migraines. However, more work is needed to find the link and the mechanism to explain how these bacteria adapt genetically to their host environment.

Therefore, there may be an optimum number and composition of nitrate reducing bacteria which has beneficial effects, and a greater level may have a negative impact on conditions associated with blood vessel dilation such as migraine. However, it should be acknowledged that nitrate reduction and metabolism cannot be attributed to single bacterial species as they are unlikely to express all of the enzymes required to decompose nitrate simultaneously. More likely, these individual nitrate reducing bacteria are considered to work in synergy with other members of the microbial community. This has been demonstrated by Hyde et al, ${ }^{43}$ who found that mixed colonies of high and low nitrate reducers showed a greater capacity for nitrate reduction than mixes of either multiple high reducers or individual nitrate reducing bacteria. This highlights the complexity of the oral microbiome and the impact on dietary nitrate metabolism.

Cardiometabolic diseases including obesity, the metabolic syndrome and type II diabetes are major contributors to global CVD disease burden. Whilst some studies have reported plasma nitrate/nitrite levels to be negatively associated with waist circumference ${ }^{94}$, obesity ${ }^{95}$ and blood pressure, others have observed positive associations between plasma nitrite and BMI, fasting blood 
562 glucose ${ }^{96}$, systolic blood pressure and the fasting lipid profile. In support of these findings, Akram 563 et al $(2018)^{97}$, found plasma nitrite levels to be higher in individuals with both obesity and the 564 metabolic syndrome followed by those with obesity alone, with the lowest levels in those with normal weight. Whether high plasma nitrite levels play a role in the worsening of the cardiometabolic risk markers is a public health issue since higher dietary nitrate intakes may also cause higher levels of plasma NOx (sum of nitrate and nitrite levels). Furthermore, these data are associations, do not indicate whether cardiometabolic risk markers change in response to varying nitrate/nitrite intakes and do not prove cause and effect. Interestingly, a review of the evidence suggests the contrary, with dietary nitrate supplementation found to reverse or improve some of the features of the metabolic syndrome and be protective against the development of CVD ${ }^{98}$. Although these beneficial effects may be related to improvements in NO metabolic pathways and glucose control, we cannot discount that favourable changes in the gut microbiota in response to dietary nitrate intake may also represent an important mechanism since dysbiosis (a term to describe microbial imbalance) is a common feature of the cardiometabolic diseases. However, very few studies have determined the impact of dietary nitrate supplementation on the gut microbiota in humans, with a very short-term study with nitrate-rich fruit and vegetable juice suggesting a reduction in the Firmicutes to Bacteroides ratio after 3 days which was related to higher plasma nitrate/nitrite levels ${ }^{99}$. Furthermore, a one-year intervention with the Mediterranean diet, rich in vegetables, was associated with increased abundance of specific taxa that were inversely associated with inflammatory markers ${ }^{100}$. More studies are needed to address this research gap which also include analysis of the oral microbiome to determine whether increases in the abundance of nitrate reducing bacteria are related to improvements in cardiovascular health.

Oral hygiene habits, including daily use of an antibacterial mouthwash or tongue scraper

586 On the other hand, poor oral hygiene contributes to dysbiosis by accumulating a plaque biofilm 587 which contains large number of microbes including nitrate reducing bacteria ${ }^{101}$. This can cause 
dental infections and gingivitis by increasing pathogenic bacteria such as (porphyromonas

589 gingivalis) ${ }^{102}$. Studies have shown that patients with periodontal disease to have higher levels of 590 salivary nitrite which may be partly derived from the reduction of nitrates by the oral bacteria. Since nitrite has been shown to have an antimicrobial effect against gastrointestinal and oral pathogens, it has been speculated that the salivary glands may respond to the periodontal infection by enhancing the secretion of nitrate and production of nitrite by the nitrate reducing bacteria as a host defence mechanism ${ }^{103}$. This is thought to reduce the prevalence of the acidogenic bacteria which contribute to the development of dental caries. In agreement, Doel et al ${ }^{42}$ has reported a significant reduction in dental carries in study participants with high salivary nitrate concentration. Epidemiological studies have reported an association between periodontal disease with CVD. Although the cause and effect relationship has not been proven, studies have suggested that inflammation caused by the oral infection may contribute to the development and progression of the atherosclerotic plaque.

600 Interestingly, periodontal pathogens have been identified in the atherosclerotic plaque suggesting a 601 direct role in CVD. However, to date, periodontal disease has not been considered to be a CVD risk marker ${ }^{104}$. Lifestyle habits such as smoking can also influence oral bacteria composition ${ }^{74}$. In a study conducted in 9 non-smokers aged $20-45$ y and $n=5$ healthy active smokers $(>20$ cigarettes per week) aged 30-60 years, nitrate reduction activity was found to be over $80 \%$ lower in smokers compared to non-smokers ${ }^{74}$. However, the low numbers of individuals within each group may have influenced the results observed.

As previously mentioned, dietary nitrates have been shown to interact with other food components such as lipids ${ }^{72}$, with similar reports for polyphenols ${ }^{105}$, alcohol ${ }^{106}$ and proteins ${ }^{25}$. In 609 particular, foods and beverages rich in polyphenols including apple, tea and orange juice have been 610 shown to lead to a 3 fold increase in NO production in the stomach ${ }^{107}$ and reduce endogenous $\mathrm{N}$ 611 nitrosamine formation. Along with polyphenols, the content of ethanol in red wine can also interact 612 with nitrite forming ethyl nitrite which works as a nitrosation agent and may mediate NO effects. 
613 These interactions with other dietary components may therefore play a role in modulating the 614 circulating NO levels and bioavailability of the nitrate and nitrite contained within foods. In summary, a systematic approach was used to identify the studies that have determined the impact of oral bacteria on blood pressure in response to nitrate intake, from dietary sources or supplements. However, only a very limited number of human $(n=2)$ and animal $(n=3)$ studies have addressed this research question, with the remaining studies examining the importance of the oral

619 bacteria on the nitrate reducing capacity on circulating nitrite concentrations and blood pressure.

620 Based on our observations from these studies, there is accumulating evidence to suggest that 621 absence of nitrate-reducing oral bacteria was associated with increasing blood pressure even when accompanied by a high nitrate intake. However, some of the studies failed to see any effects, which may be due to type of mouthwash used in the human studies or the method of application of the mouthwash in the animal study ${ }^{29}$. Sex, hypertension, and tongue cleaning were all found to be important potential determinants of the variability in the responses between participants. Of these, the dental hygiene practice of tongue cleaning, which is recommended by the American Dental Association, appeared to promote oral microbiota diversity and be associated with a greater ability to recover the tongue microbiome after mouthwash use. Potential mechanisms to explain the blood pressure lowering effects of dietary nitrates included increases in plasma nitrite, S-nitrosothiols, nitro-fatty acids and vascular nitrosylation and cross-talk between the enterosalivary nitrate-nitrite-

631 NO pathways and eNOS activity in the endothelial cells. However, the limited number of studies performed make it difficult to draw any firm conclusions from this literature review.

\section{Conclusions}

635 With the increasing prevalence of non-communicable diseases there is an urgent need for further studies to investigate the role of the oral bacteria on cardiovascular health in response to dietary nitrate intake, and to determine the underlying mechanisms. With vascular function now recognised as an important prognostic marker for future CVD risk, studies incorporating real time measures of 
639 vascular reactivity and tone are required. Furthermore, the use of rigorous methods to determine 640 changes in the abundance and composition of the oral bacteria in response to intake of dietary 641 nitrate would help to identify important nitrate-reducing bacteria related to changes in vascular 642 function and determine whether these bacterial groups are also evident in the gut microbiome, a 643 proposed modulator of chronic disease risk. Diets containing nitrate-rich foods may contain other 644 bioactive components which could also contribute to CVD risk reduction, including fibres, 645 vitamins, minerals and flavonoids. Such diets may offer a number of advantages over nitrate/nitrite 646 supplemental use, not only due to the availability of other bioactive components, but also because 647 of reports of vascular adaptation and risk of marked acute hypotension after supplemental nitrate 648 use, not found with nitrate-rich diets ${ }^{108}$. With hypertension a major risk factor for CVD, more 649 studies are needed to determine whether diets higher in nitrate-rich foods can be recommended for 650 blood pressure lowering and disease prevention in healthy individuals and those at greater CVD 651 risk.

\section{Acknowledgements and Author Contributions:}

654 The authors responsibilities were as follows: H.S.A., D.A.H, K.G.J. and J.A.L. contributed to the 655 conception of the literature search strategy. H.S.A. undertook the literature review. D.A.H., K.G.J. 656 and J.A.L. provided feedback and guidance on previous drafts of the review and J.A.L. was 657 responsible for final content. The authors have no conflicts of interest to declare.

\section{Financial support}

660 H.S.A was supported by a PhD studentship funded by King Saud University (Saudi Arabia). This 661 research received no specific grant from any funding agency, and commercial. 


\section{References:}

1. Mathers CD, Loncar D. Projections of global mortality and burden of disease from 2002 to 2030. PLoS Med. 2006;3(11):2011-2030. doi:10.1371/journal.pmed.0030442

2. Isaura ER, Chen YC, Yang SH. The association of food consumption scores, body shape index, and hypertension in a seven-year follow-up among Indonesian adults: A longitudinal study. Int J Environ Res Public Health. 2018;15(1). doi:10.3390/ijerph15010175

3. Weir S, Juhasz A, Puelles J, Tierney TS. Relationship between initial therapy and blood pressure control for high-risk hypertension patients in the UK: A retrospective cohort study from the THIN general practice database. BMJ Open. 2017;7(7):1-10. doi:10.1136/bmjopen2016-015527

4. Public Health Engeland. Health matters: combating high blood pressure. GOV.UK. https://www.gov.uk/government/publications/health-matters-combating-high-bloodpressure/health-matters-combating-high-blood-pressure\#contents. Published 2017.

5. Bryan N. Functional nitric oxide nutrition to combat cardiovascular disease. Springer. 2018. https://idp.springer.com/authorize/casa?redirect_uri=https://link.springer.com/article/10.1007 /s11883-018-0723-

0\&casa_token=O78oJS89q3QAAAAA:h3aWMir4VaSdz1PgDjrgyfxcli3hFqCKQGiRkcNQ zOpMn0MSRyk2DR8_bS16JsTPMmabG2ATDEPqJreVgQ.

6. Jones NRV, Tong TYN, Monsivais P. Meeting UK dietary recommendations is associated with higher estimated consumer food costs: An analysis using the National Diet and Nutrition Survey and consumer expenditure data, 2008-2012. Public Health Nutr. 2018;21(5):948-956. doi:10.1017/S1368980017003275

7. Siervo M, Lara J, Chowdhury S, Ashor A, Oggioni C, Mathers JC. Effects of the dietary approach to stop hypertension (DASH) diet on cardiovascular risk factors: A systematic 
review and meta-analysis. Br J Nutr. 2015;113(1):1-15. doi:10.1017/S0007114514003341

8. Serra-Majem L, Roman B, Estruch R. Scientific evidence of interventions using the Mediterranean diet: a systematic review. Nutr Rev. 2006;64(2 Pt 2):S27-47. doi:10.1301/nr.2006.feb.S27

9. Bhupathiraju SN, Wedick NM, Pan A, et al. Quantity and variety in fruit and vegetable intake and risk of coronary heart disease. Am J Clin Nutr. 2013;98(4):1514-1523. doi:10.3945/ajen.113.066381.1

10. Bahadoran Z, Mirmiran P, Kabir A, Azizi F, Ghasemi A. The Nitrate-Independent Blood Pressure-Lowering Effect of Beetroot Juice: A Systematic Review and Meta-Analysis. Adv Nutr An Int Rev J. 2017;8(6):830-838. doi:10.3945/an.117.016717

11. Larsen FJ, Ekblom B, Sahlin K, Lundberg JO, Weitzberg E. Effects of Dietary Nitrate on Blood Pressure in Healthy Volunteers. N Engl J Med. 2006;355(26):2792-2793. doi:10.1056/NEJMc062800

12. Broxterman RM, La Salle DT, Zhao J, Reese VR, Richardson RS, Trinity JD. Influence of dietary inorganic nitrate on blood pressure and vascular function in hypertension: prospective implications for adjunctive treatment. J Appl Physiol. 2019;127(4):1085-1094. doi:10.1152/japplphysiol.00371.2019

13. D'El-Rei J, Cunha AR, Trindade M, Neves MF. Beneficial effects of dietary nitrate on endothelial function and blood pressure levels. Int J Hypertens. 2016;2016. doi:10.1155/2016/6791519

14. Velmurugan S, Gan JM, Rathod KS, et al. Dietary nitrate improves vascular function in patients with hypercholesterolemia : a randomized, double-blind, placebo-controlled study. Am J Clin Nutr. 2016;103(July):25-38. doi:10.3945/ajcn.115.116244.25

15. Lidder S, Webb AJ. Vascular effects of dietary nitrate (as found in green leafy vegetables 
and beetroot) via the nitrate-nitrite-nitric oxide pathway. Br J Clin Pharmacol. 2013;75(3):677-696. doi:10.1111/j.1365-2125.2012.04420.x

16. Jackson JK, Patterson AJ, MacDonald-Wicks LK, Oldmeadow C, McEvoy MA. The role of inorganic nitrate and nitrite in cardiovascular disease risk factors: A systematic review and meta-analysis of human evidence. Nutr Rev. 2018;76(5):348-371. doi:10.1093/nutrit/nuy005

17. Blekkenhorst LC, Bondonno NP, Liu AH, et al. Nitrate, the oral microbiome, and cardiovascular health: a systematic literature review of human and animal studies. Am J Clin Nutr. 2018;107(4):504-522. doi:10.1093/ajcn/nqx046

18. Khambata RS, Ghosh SM, Rathod KS, et al. Antiinflammatory actions of inorganic nitrate stabilize the atherosclerotic plaque. Proc Natl Acad Sci. 2017;114(4):E550-E559. doi:10.1073/pnas.1613063114

19. Webb AJ, Patel N, Loukogeorgakis S, et al. Acute blood pressure lowering, vasoprotective and anti-platlet properties of dietary nitrate via bioconversion to nitrate. Hypertension. 2008;51(3):784-790. doi:10.1161/HYPERTENSIONAHA.107.103523.Acute

20. Eggebeen J, Kim-Shapiro D, Haykowsky M, et al. One week of daily dosing with beetroot juice improves submaximal endurance and blood pressure in older patients with heart failure and preserved ejection fraction. JACC Hear Fail. 2016;4(6):428-437. doi:10.1016/j.jchf.2015.12.013.One

21. Liu AH, Bondonno CP, Russell J, et al. Relationship of dietary nitrate intake from vegetables with cardiovascular disease mortality: a prospective study in a cohort of older Australians. Eur J Nutr. 2018;0(0):0. doi:10.1007/s00394-018-1823-x

22. Gee LC, Ahluwalia A. Dietary Nitrate Lowers Blood Pressure: Epidemiological, Pre-clinical Experimental and Clinical Trial Evidence. Curr Hypertens Rep. 2016;18(2):1-14. doi:10.1007/s11906-015-0623-4 
23. Koutsoumanis K, Allende A, Alvarez-Ordóñez A, et al. Scientific Opinion on the update of the list of QPS-recommended biological agents intentionally added to food or feed as notified to EFSA (2017-2019). EFSA J. 2020;18(2). doi:10.2903/j.efsa.2020.5966

24. Knobeloch L, Salna B, Hogan A, Postle J, Anderson H. Blue babies and nitrate-contaminated well water. Environ Health Perspect. 2000;108(7):675-678. doi:10.1289/ehp.00108675

25. World Cancer Research Fund AI for CR. Diet, nutrition, physical activity and colorectal cancer: Continuous Update Project 2017. 2017:111. http://www.aicr.org/continuous-updateproject/reports/colorectal-cancer-2017-report.pdf.

26. Bryan NS, Tribble G, Angelov N. Oral Microbiome and Nitric Oxide: the Missing Link in the Management of Blood Pressure. Curr Hypertens Rep. 2017;19(4). doi:10.1007/s11906017-0725-2

27. Govoni M, Jansson EA, Weitzberg E, Lundberg JO. The increase in plasma nitrite after a dietary nitrate load is markedly attenuated by an antibacterial mouthwash. Nitric Oxide - Biol Chem. 2008;19(4):333-337. doi:10.1016/j.niox.2008.08.003

28. Hezel MP, Weitzberg E. The oral microbiome and nitric oxide homoeostasis. 2015:7-16. doi:10.1111/odi.12157

29. Hyde E, Luk B, Tribble GD, Bryan NS. Characterization of the rat oral microbiome and the Effects of dietary nitrate . Free Radic Biol Med. 2014;77(October):249-257. doi:10.1016/j.freeradbiomed.2014.09.017

30. Woessner M, Smoliga JM, Tarzia B, Stabler T, Van Bruggen M, Allen JD. A stepwise reduction in plasma and salivary nitrite with increasing strengths of mouthwash following a dietary nitrate load. Nitric Oxide - Biol Chem. 2016;54:1-7. doi:10.1016/j.niox.2016.01.002

31. Al Khodor S, Reichert B, Shatat IF. The Microbiome and Blood Pressure: Can Microbes Regulate Our Blood Pressure? Front Pediatr. 2017;5(June):1-12. 
doi:10.3389/fped.2017.00138

32. Ma L, Hu L, Feng X, Wang S. Nitrate and nitrite in health and disease. Aging Dis. 2018;9(5):938-945. doi:10.14336/AD.2017.1207

33. Goh CE, Trinh P, Colombo PC, et al. Association Between Nitrate-Reducing Oral Bacteria and Cardiometabolic Outcomes: Results From ORIGINS. J Am Heart Assoc. 2019;8(23):e013324. doi:10.1161/JAHA.119.013324

34. Raju TN. The Nobel chronicles. 1998: Robert Francis Furchgott (b 1911), Louis J Ignarro (b 1941), and Ferid Murad (b 1936). Lancet (London, England). 2000;356(9226):346. doi:10.1016/S0140-6736(05)73635-7

35. Parthasarathy DK, Bryan NS. Sodium nitrite: The "cure" for nitric oxide insufficiency. Meat Sci. 2012;92(3):274-279. doi:10.1016/j.meatsci.2012.03.001

36. Xu KY, Huso DL, Dawson TM, Bredt DS, Becker LC. Nitric oxide synthase in cardiac sarcoplasmic reticulum. Proc Natl Acad Sci. 1999;96(2):657-662. doi:10.1073/pnas.96.2.657

37. Kelm M. Nitric oxide metabolism and breakdown. Biochim Biophys Acta-Bioenerg. 1999;1411(2-3):273-289. doi:10.1016/S0005-2728(99)00020-1

38. Hord NG, Tang Y, Bryan NS. Food sources of nitrates and nitrites : the physiologic context for. 2009;(6):1-10. doi:10.3945/ajen.2008.27131.INTRODUCTION

39. Brkić D, Bošnir J, Bevardi M, et al. NITRATE IN LEAFY GREEN VEGETABLES AND ESTIMATED INTAKE. 2017;14:31-41.

40. Burleigh MC, Liddle L, Monaghan C, et al. Salivary nitrite production is elevated in individuals with a higher abundance of oral nitrate-reducing bacteria. Free Radic Biol Med. 2018;120(December 2017):80-88. doi:10.1016/j.freeradbiomed.2018.03.023

41. Kapil V, Haydar SMA, Pearl V, Lundberg JO, Weitzberg E, Ahluwalia A. Physiological role 
for nitrate-reducing oral bacteria in blood pressure control. Free Radic Biol Med. 2013;55:93-100. doi:10.1016/j.freeradbiomed.2012.11.013

42. Doel JJ, Benjamin N, Hector MP, Rogers M, Allaker RP. Evaluation of bacterial nitrate reduction in the human oral cavity. Eur J Oral Sci. 2005;113(1):14-19. doi:10.1111/j.16000722.2004.00184.x

43. Hyde ER, Andrade F, Vaksman Z, et al. Metagenomic Analysis of Nitrate-Reducing Bacteria in the Oral Cavity : Implications for Nitric Oxide Homeostasis. 2014;9(3). doi:10.1371/journal.pone.0088645

44. Koch CD, Gladwin MT, Freeman BA, Lundberg JO, Weitzberg E, Morris A. Enterosalivary nitrate metabolism and the microbiome: Intersection of microbial metabolism, nitric oxide and diet in cardiac and pulmonary vascular health. Free Radic Biol Med. 2017;105(September 2016):48-67. doi:10.1016/j.freeradbiomed.2016.12.015

45. Iijima K, Henry E, Moriya A, Wirz A, Kelman AW, McColl KEL. Dietary nitrate generates potentially mutagenic concentrations of nitric oxide at the gastroesophageal junction. Gastroenterology. 2002;122(5):1248-1257. doi:10.1053/gast.2002.32963

46. Sobko T, Huang L, Midtvedt T, et al. Generation of NO by probiotic bacteria in the gastrointestinal tract. Free Radic Biol Med. 2006;41(6):985-991. doi:10.1016/j.freeradbiomed.2006.06.020

47. Petersson J, Phillipson M, Jansson EÅ, Patzak A, Lundberg JO, Holm L. Dietary nitrate increases gastric mucosal blood flow and mucosal defense. Am J Physiol - Gastrointest Liver Physiol. 2007;292(3):718-724. doi:10.1152/ajpgi.00435.2006

48. Waldum HL, Kleveland PM, Sørdal ØF. Helicobacter pylori and gastric acid: An intimate and reciprocal relationship. Therap Adv Gastroenterol. 2016;9(6):836-844. doi:10.1177/1756283X16663395 
49. Gilchrist M, Shore AC, Benjamin N. Inorganic nitrate and nitrite and control of blood pressure. Cardiovasc Res. 2011;89(3):492-498. doi:10.1093/cvr/cvq309

50. Lundberg JO, Weitzberg E. Biology of nitrogen oxides in the gastrointestinal tract. 2013:616-629. doi:10.1136/gutjnl-2011-301649

51. Bos PMJ, Wedel M, Hezel MP, et al. Nitric Oxide Microbiota and the nitrogen cycle : Implications in the development and progression of CVD and CKD. Free Radic Biol Med. 2017;55(4):64-70. doi:10.1007/s11906-017-0725-2

52. Undberg JOL. Nitric Oxide in the Gastrointestinal Tract : Role of Bacteria. 2008;27(4):109112.

53. Petra CV, Rus A, Dumitrașcu DANL. GASTRIC MICROBIOTA : TRACING THE CULPRIT. 2017;90(4):369-376. doi:10.15386/cjmed-854

54. Forsythe SJ, Dolbyt JM, Websters ADB, Cole JA, Box PO, Birmingham BTT. Nitrate- and nitrite-reducing bacteria in the achlorhydric stomach. 2018;25(1988):253-259.

55. Tiso M, Schechter AN. Nitrate Reduction to Nitrite, Nitric Oxide and Ammonia by Gut Bacteria under Physiological Conditions. 2015:1-18. doi:10.1371/journal.pone.0119712

56. Sobko T, Reinders C, Norin E, et al. Gastrointestinal nitric oxide generation in germ-free and conventional rats. 2018:993-997. doi:10.1152/ajpgi.00203.2004.

57. Parham NJ, Gibson GR. Microbes involved in dissimilatory nitrate reduction in the human large intestine. 2000;31.

58. Sobko T, Reinders CI, Jansson EÅ, Norin E, Midtvedt T, Lundberg JO. Gastrointestinal bacteria generate nitric oxide from nitrate and nitrite. 2005;13:272-278. doi:10.1016/j.niox.2005.08.002

59. Briskey D, Tucker PS, Johnson DW, Coombes JS. Microbiota and the nitrogen cycle: 
Implications in the development and progression of CVD and CKD. Nitric Oxide - Biol Chem. 2016;57:64-70. doi:10.1016/j.niox.2016.05.002

60. Marsh PD, Head DA, Devine DA. Ecological approaches to oral biofilms: Control without killing. Caries Res. 2015;49(suppl 1):46-54. doi:10.1159/000377732

61. Ji B, Yang K, Zhu L, et al. Aerobic denitrification: A review of important advances of the last 30 years. Biotechnol Bioprocess Eng. 2015;20(4):643-651. doi:10.1007/s12257-0150009-0

62. Schreiber F, Stief P, Gieseke A, et al. Denitrification in human dental plaque. Bmc Biol. 2010;8(3). doi:24\r10.1186/1741-7007-8-24

63. Takaya N, Catalan-sakairi MAB, Sakaguchi Y, Kato I, Zhou Z, Shoun H. Aerobic denitrifying bacteria- AEM.pdf. 2003;69(6):3152-3157. doi:10.1128/AEM.69.6.3152

64. Sparacino-Watkins C, Stolz JF, Basu P. Nitrate and periplasmic nitrate reductases. AUTHOR'S MANUSCRIPT. Chem Soc Rev. 2014;43(2):676-706. doi:10.1039/c3cs60249d

65. Herrero A, Flores E, Imperial J. Nitrogen Assimilation in Bacteria. Ref Modul Life Sci. January 2019. doi:10.1016/B978-0-12-809633-8.20680-8

66. Dodsworth JA, Hungate BA, Hedlund BP. Ammonia oxidation, denitrification and dissimilatory nitrate reduction to ammonium in two US Great Basin hot springs with abundant ammonia-oxidizing archaea. Environ Microbiol. 2011;13(8):2371-2386. doi:10.1111/j.1462-2920.2011.02508.x

67. Tomasova L, Konopelski P, Ufnal M. Gut bacteria and hydrogen sulfide: The new old players in circulatory system homeostasis. Molecules. 2016;21(11):1-18. doi:10.3390/molecules21111558

68. Higgins JPT, Sterne JAC, Savović J, et al. A revised tool for assessing risk of bias in randomized trials. Cochrane Methods Cochrane Database Syst Rev 2016. 
69. Hooijmans CR, Rovers MM, De Vries RBM, Leenaars M, Ritskes-Hoitinga M, Langendam MW. SYRCLE's risk of bias tool for animal studies. BMC Med Res Methodol. 2014;14(1):19. doi:10.1186/1471-2288-14-43

70. Petersson J, Carlström M, Schreiber O, et al. Gastroprotective and blood pressure lowering effects of dietary nitrate are abolished by an antiseptic mouthwash. Free Radic Biol Med. 2009;46(8):1068-1075. doi:10.1016/j.freeradbiomed.2009.01.011

71. Pinheiro LC, Ferreira GC, Amaral H, et al. Oral nitrite circumvents antiseptic mouthwashinduced disruption of entrosalivary circuit of nitrate and promotes nitrosation and blood pressure lowring effect. 2016;101(July):226-235. doi:10.1016/j.freeradbiomed.2016.10.013

72. Delmastro-Greenwood M, Hughan KS, Vitturi DA, et al. Nitrite and nitrate-dependent generation of anti-inflammatory fatty acid nitroalkenes. Free Radic Biol Med. 2015;89:333341. doi:10.1016/j.freeradbiomed.2015.07.149

73. Montenegro MF, Sundqvist ML, Nihlén C, et al. Profound differences between humans and rodents in the ability to concentrate salivary nitrate: Implications for translational research. Redox Biol. 2016;10(October):206-210. doi:10.1016/j.redox.2016.10.011

74. Ahmed KA, Nichols AL, Honavar J, Dransfield MT, Matalon S, Patel RP. Measuring nitrate reductase activity from human and rodent tongues. Nitric Oxide - Biol Chem. 2017;66:62-70. doi:10.1016/j.niox.2017.04.001

75. Mitsui T, Harasawa R. The effects of essential oil, povidone-iodine, and chlorhexidine mouthwash on salivary nitrate/nitrite and nitrate-reducing bacteria. J Oral Sci. 2017;59(4):597-601. doi:10.2334/josnusd.16-0593

76. Bondono p C, Croft DK, Considin JM, Puddey b I, Yang X. nitrate causes a dose-dependent augmentation of nitric oxide status in healthy wome. Sex Roles. 2012;23(5):269-282. 
doi:10.1016/j.jadohealth.2015.04.026

77. Bondonno CP, Liu AH, Croft KD, et al. Antibacterial mouthwash blunts oral nitrate reduction and increases blood pressure in treated hypertensive men and women. Am J Hypertens. 2015;28(5):572-575. doi:10.1093/ajh/hpu192

78. Tribble GD, Angelov N, Weltman R, et al. Frequency of Tongue Cleaning Impacts the Human Tongue Microbiome Composition and Enterosalivary Circulation of Nitrate. Front Cell Infect Microbiol. 2019;9(March):1-16. doi:10.3389/fcimb.2019.00039

79. Sundqvist ML, Lundberg JO, Weitzberg E. Effects of antiseptic mouthwash on resting metabolic rate: A randomized, double-blind, crossover study. Nitric Oxide - Biol Chem. 2016;61:38-44. doi:10.1016/j.niox.2016.10.003

80. McDonagh STJ, Wylie LJ, Winyard PG, Vanhatalo A, Jones AM. The effects of chronic nitrate supplementation and the use of strong and weak antibacterial agents on plasma nitrite concentration and exercise blood pressure. Int J Sports Med. 2015;36(14):1177-1185. doi:10.1055/s-0035-1554700

81. Sandell MA, Collado MC. Genetic variation in the TAS2R38 taste receptor contributes to the oral microbiota in North and South European locations : a pilot study. 2018:1-9.

82. Li J, Li M, Rzhetskaya M, et al. Comparative analysis of the human saliva microbiome from different climate zones: Alaska, Germany, and Africa. BMC Microbiol. 2014;14(1):1-13. doi:10.1186/s12866-014-0316-1

83. Hansen TH, Kern T, Bak EG, et al. Impact of a vegan diet on the human salivary microbiota. Sci Rep. 2018;8(1):1-11. doi:10.1038/s41598-018-24207-3

84. Eldeghaidy S, Thomas D, Skinner M, et al. An automated method to detect and quantify fungiform papillae in the human tongue: Validation and relationship to phenotypical differences in taste perception. Physiol Behav. 2018;184(December 2017):226-234. 
doi:10.1016/j.physbeh.2017.12.003

85. Kishi M, Ohara-Nemoto Y, Takahashi M, Kishi K, Kimura S, Yonemitsu M. Relationship between oral status and prevalence of periodontopathic bacteria on the tongues of elderly individuals. J Med Microbiol. 2010;59(11):1354-1359. doi:10.1099/jmm.0.020636-0

86. Vanhatalo A, Blackwell JR, L'Heureux JE, et al. Nitrate-responsive oral microbiome modulates nitric oxide homeostasis and blood pressure in humans. Free Radic Biol Med. 2018;124(May):21-30. doi:10.1016/j.freeradbiomed.2018.05.078

87. Kapil V, Rathod KS, Khambata RS, et al. Sex differences in the nitrate-nitrite-NO pathway: role of oral nitrate-reducing bacteria. Free Radic Biol Med. 2018. doi:10.1016/j.freeradbiomed.2018.07.010

88. Liddle L, Burleigh MC, Monaghan C, et al. Variability in nitrate-reducing oral bacteria and nitric oxide metabolites in biological fluids following dietary nitrate administration: An assessment of the critical difference. Nitric Oxide. 2019;83:1-10.

doi:10.1016/J.NIOX.2018.12.003

89. Koopman JE, Buijs MJ, Brandt BW, Keijser BJF, Crielaard W, Zaura E. Nitrate and the Origin of Saliva Influence Composition and Short Chain Fatty Acid Production of Oral Microcosms. Microb Ecol. 2016;72(2):479-492. doi:10.1007/s00248-016-0775-z

90. Hohensinn B, Haselgrübler R, Müller U, et al. Sustaining elevated levels of nitrite in the oral cavity through consumption of nitrate-rich beetroot juice in young healthy adults reduces salivary pH. Nitric Oxide - Biol Chem. 2016;60(2):10-15. doi:10.1016/j.niox.2016.08.006

91. Gordon JH, LaMonte MJ, Genco RJ, Zhao J, Li L. Is the Oral Microbiome Associated with Blood Pressure in Older Women? High Blood Press Cardiovasc Prev. 26(3):217-225. doi:10.1007/s40292-019-00322-8

92. Stellato G, Utter DR, Voorhis A, Angelis M De, Eren AM. A Few Pseudomonas Oligotypes 
Dominate in the Meat and Dairy Processing Environment. 2017;8(March):1-9.

doi:10.3389/fmicb.2017.00264

93. Gonzalez A, Hyde E, Sangwan N, Gilbert JA, Viirre E, Knight R. Migraines Are Correlated with Higher Levels of Nitrate-, Nitrite-, and Nitric Oxide-Reducing Oral Microbes in the American Gut Project Cohort. mSystems. 2016;1(5):e00105-16.

doi:10.1128/mSystems.00105-16

94. Kondo T, Ueyama J, Imai R, Suzuki K, Ito Y. Association of abdominal circumference with serum nitric oxide concentration in healthy population. Environ Health Prev Med. 2006;11(6):321-325. doi:10.1265/ehpm.11.321

95. Piva SJ, Tatsch E, De Carvalho JAM, et al. Assessment of inflammatory and oxidative biomarkers in obesity and their associations with body mass index. Inflammation. 2013;36(1):226-231. doi:10.1007/s10753-012-9538-2

96. Li R, Lyn D, Lapu-Bula R, et al. Relation of endothelial nitric oxide synthase gene to plasma nitric oxide level, endothelial function, and blood pressure in African Americans. Am J Hypertens. 2004;17(7):560-567. doi:10.1016/j.amjhyper.2004.02.013

97. Akram F, Fuchs D, Daue M, et al. Association of plasma nitrite levels with obesity and metabolic syndrome in the Old Order Amish. Obes Sci Pract. 2018;4(5):468-476. doi:10.1002/osp4.290

98. Lundberg JO, Carlström M, Weitzberg E. Metabolic Effects of Dietary Nitrate in Health and Disease. Cell Metab. 2018;28(1):9-22. doi:10.1016/j.cmet.2018.06.007

99. Henning SM, Yang J, Shao P, et al. Health benefit of vegetable/fruit juice-based diet: Role of microbiome /631/326/41/2533/692/308/409/9 /45/23 article. Sci Rep. 2017;7(1):1-9. doi:10.1038/s41598-017-02200-6

100. Ghosh TS, Rampelli S, Jeffery IB, et al. Mediterranean diet intervention alters the gut 
microbiome in older people reducing frailty and improving health status: The NU-AGE 1year dietary intervention across five European countries. Gut. 2020;69(7):1218-1228. doi:10.1136/gutjnl-2019-319654

101. Kilian M, Chapple ILC, Hannig M, et al. The oral microbiome - an update for oral healthcare professionals. Br Dent J. 2016;221(10):657-666. doi:10.1038/sj.bdj.2016.865

102. Kishi M, Ohara-Nemoto Y, Takahashi M, Kishi K, Kimura S, Yonemitsu M. Relationship between oral status and prevalence of periodontopathic bacteria on the tongues of elderly individuals. J Med Microbiol. 2010;59(11):1354-1359. doi:10.1099/jmm.0.020636-0

103. Qu XM, Wu ZF, Pang BX, Jin LY, Qin LZ, Wang SL. From Nitrate to Nitric Oxide: The Role of Salivary Glands and Oral Bacteria. J Dent Res. 2016;95(13):1452-1456. doi:10.1177/0022034516673019

104. Liccardo D, Cannavo A, Spagnuolo G, et al. Periodontal disease: A risk factor for diabetes and cardiovascular disease. Int J Mol Sci. 2019;20(6). doi:10.3390/ijms20061414

105. Lovegrove JA, Stainer A, Hobbs DA. Role of flavonoids and nitrates in cardiovascular health. Proc Nutr Soc. 2017;76(2):83-95. doi:10.1017/S0029665116002871

106. McDonagh STJ, Wylie LJ, Morgan PT, Vanhatalo A, Jones AM. A randomised controlled trial exploring the effects of different beverages consumed alongside a nitrate-rich meal on systemic blood pressure. Nutr Health. 2018;24(3):183-192. doi:10.1177/0260106018790428

107. Gago B, Nyström T, Cavaleiro C, et al. The potent vasodilator ethyl nitrite is formed upon reaction of nitrite and ethanol under gastric conditions. Free Radic Biol Med. 2008;45(4):404-412. doi:10.1016/J.FREERADBIOMED.2008.04.027

108. Omar SA, Artime E, Webb AJ. A comparison of organic and inorganic nitrates/nitrites. Nitric Oxide - Biol Chem. 2012;26(4):229-240. doi:10.1016/j.niox.2012.03.008 
Tables

Table1: Commonly reported nitrate reducing bacteria species found in the oral cavity

\begin{tabular}{|c|c|c|c|}
\hline Bacteria species & Condition & Change in abundance in response to nitrate intake & Location in the oral cavity \\
\hline Veillonella dispar ${ }^{42,43}$ & Anaerobic & $\uparrow$ & Tongue \\
\hline Actinomyces odontolyticus ${ }^{42,43}$ & Facultative anaerobic & $\uparrow$ & Tongue \\
\hline Prevotella salivae 42,43 & Anaerobic & $\uparrow$ & Tongue \\
\hline Rothia mucilaginosa $a^{42,14}$ & Aerobic & $\uparrow \uparrow$ & Tongue \\
\hline Neisseria flavescens $s^{43,14}$ & Aerobic & $\uparrow \uparrow$ & Tongue \\
\hline
\end{tabular}


Table 2: Animal studies investigating the importance of oral nitrate reducing bacteria on blood pressure in response to nitrate intake.

\begin{tabular}{|c|c|c|c|c|c|}
\hline Reference & Animals & Study design and duration & Intervention & Measurement & Outcome measures \\
\hline \multirow[t]{5}{*}{$\begin{array}{l}\text { Petersson } \\
2009^{70}\end{array}$} & \multirow{5}{*}{$\begin{array}{l}\mathrm{n}=4-7 \text { Male Sprague } \\
\text { Dawley rats each } \\
\text { group (190-360 g, B } \\
\text { and K, Sollentwia, } \\
\text { Sverge). }\end{array}$} & \multirow{5}{*}{$\begin{array}{l}\text { Parallel groups with } 7 \text { day } \\
\text { treatment periods: } \\
\text { 1) No treatment (control). } \\
\text { 2) } \mathrm{NaNO}_{3} \text { only } \\
\text { 3) Mouthwash } \\
\text { 4) Mouthwash }+\mathrm{NaNO}_{3} \\
\text { or } \mathrm{NaNO}_{2}\end{array}$} & \multirow{5}{*}{$\begin{array}{l}\text { Water supplemented with } \\
10 \mathrm{mM} \mathrm{NaNO}_{3} \text { or } 1 \mathrm{mM} \\
\mathrm{NaNO}_{2} \\
\text { Mouthwash groups: } \\
\text { Chlorhexidine mouthwash } \\
\text { spray }(0.3 \mathrm{ml}), 2 \mathrm{X} \text { daily. }\end{array}$} & Plasma & $\begin{array}{l}\Delta \mathrm{NO}_{2} \downarrow \text { after mouthwash }+ \\
\mathrm{NaNO}_{3} \text { vs control } \mathrm{p}<0.05 .\end{array}$ \\
\hline & & & & $\begin{array}{l}\text { HR } \\
\text { SBP }\end{array}$ & $\begin{array}{l}\mathrm{NS} \\
\mathrm{NS}\end{array}$ \\
\hline & & & & DBP & $\begin{array}{l}\downarrow \text { after } \mathrm{NaNO}_{3} \text {. DBP lowering } \\
\text { absent in mouthwash treated } \\
\text { rats }\end{array}$ \\
\hline & & & & MAP & $\begin{array}{l}\downarrow \text { after } \mathrm{NaNO}_{3} \text { and } \\
\text { mouthwash }+\mathrm{NaNO}_{2} \text { vs } \\
\text { mouthwash only. MAP } \\
\text { lowering absent in } \\
\text { mouthwash }+\mathrm{NaNO}_{3} \text { rats }\end{array}$ \\
\hline & & & & Oral bacteria & $\begin{array}{l}\downarrow \text { viable bacteria on tongue } \\
\text { after mouthwash }\end{array}$ \\
\hline \multirow[t]{4}{*}{$\begin{array}{l}\text { Hyde } \\
2014^{29}\end{array}$} & \multirow[t]{4}{*}{$\begin{array}{l}\mathrm{n}=8 \text { Male Wistar rats } \\
7 \text { weeks old }\end{array}$} & \multirow{4}{*}{$\begin{array}{l}19 \text { day sequential intervention: } \\
0-5 \text { control (water) } \\
6-12 \mathrm{NaNO}_{3} \text {, } \\
13-19 \mathrm{NaNO}_{3}+\text { mouthwash } \\
\text { Blood collected at day } 1,5,6 \text {, } \\
12,13 \& 19 . \mathrm{BP} \text { (telemetry) } \\
\text { and tongue swab every day }\end{array}$} & \multirow{4}{*}{$\begin{array}{l}\mathrm{NaNO}_{3}(1 \mathrm{~g} / \mathrm{L}) \text { in drinking } \\
\text { water } \\
\text { Mouthwash regime: } 0.3 \mathrm{ml} \\
\text { of chlorohexidine applied } \\
2 \mathrm{X} \text { daily to tongue dorsal } \\
\text { surface (days 13-19) }\end{array}$} & SBP & NS \\
\hline & & & & DBP & $\begin{array}{l}\downarrow \text { after } \mathrm{NaNO}_{3} \text { and } \\
\text { mouthwash }+\mathrm{NaNO}_{3} \text { vs } \\
\text { control }\end{array}$ \\
\hline & & & & & \\
\hline & & & & Plasma NOx & NS \\
\hline
\end{tabular}




\begin{tabular}{|c|c|c|c|c|c|}
\hline $\begin{array}{l}\text { Pinheiro } \\
2016^{71}\end{array}$ & $\begin{array}{l}\mathrm{n}=10, \text { Male Wistar } \\
\text { rats each group (190- } \\
210 \mathrm{~g}) \\
2 \text { kidney, } 1 \text { clip } \\
(2 \mathrm{~K} 1 \mathrm{C}) \text { hypertensive } \\
\text { group. } \\
\text { Sham operated control } \\
\text { group }\end{array}$ & $\begin{array}{l}6 \text { weeks - } 2 \text { weeks baseline } \\
\text { followed by } 4 \text { weeks treatment } \\
\text { Experiment } 1 \\
\text { Vehicle } \\
\mathrm{NaNO}_{2} \\
\text { Mouthwash } \\
\text { Mouthwash }+\mathrm{NaNO}_{2} \\
\text { Experiment } 2 \\
\text { Vehicle } \\
\text { NaNO } \\
\text { Mouthwash } \\
\text { Mouthwash + NaNO } 3 \\
6 \text { h after last treatment, blood } \\
\text { and tongue swab collected. }\end{array}$ & $\begin{array}{l}15 \mathrm{mg} \mathrm{NaNO} / \mathrm{kg} \text { or } 140 \\
\mathrm{mg} \mathrm{NaNO}_{3} / \mathrm{kg} \text { (gavage) } \\
\text { Mouthwash groups: Daily } \\
\text { mouth clean with } \\
\text { Chlorhexidine }(0.12 \%) \\
\text { soaked swab. }\end{array}$ & 更 & $\begin{array}{l}\Delta \mathrm{NO}_{2} \downarrow 25-30 \% \text { after } \\
\text { mouthwash vs } \mathrm{NaNO}_{2} \text { and } \\
\mathrm{NaNO}_{3} \text { groups }(\mathrm{P}<0.05) \\
\Delta \mathrm{NO}_{3} \downarrow 45 \% \text { after } \\
\text { mouthwash vs } \mathrm{NaNO}_{2} \text { group } \\
(\mathrm{P}<0.05) \\
\downarrow \mathrm{SBP}(40 \mathrm{mmHg}) \text { and } \mathrm{MAP} \\
\text { with } \mathrm{NaNO}_{2} \text { and } \mathrm{NaNO}_{3}(\mathrm{P}= \\
0.01) . \\
\text { Mouthwash blunted MAP } \\
\text { and } \mathrm{SBP}_{\text {lowering effect of }} \\
\mathrm{NaNO}_{3} \text { (p <0.05) but not } \\
\mathrm{NaNO}_{2} \\
\downarrow \mathrm{CFU} 50-70 \% \text { with } \\
\text { mouthwash }\end{array}$ \\
\hline
\end{tabular}

Abbreviations: DBP: Diastolic Blood Pressure, HR: Heart Rate, MAP: Mean Arterial Pressure, NS: Not Significant, $\mathrm{NO}_{2}$ : Nitrite Concentration, SBP:

Systolic Blood Pressure, $\mathrm{NO}_{3}$ : Nitrite Concentration, $\mathrm{CFU}$ : Colony Forming Unit (number of viable bacteria) 
Table 3: Human studies determining the effects of oral bacteria on salivary and plasma nitrite concentrations, and/or blood pressure in

response to nitrate intake.

\begin{tabular}{|c|c|c|c|c|c|c|}
\hline Reference & $\begin{array}{l}\text { Subject } \\
\text { characteristics }\end{array}$ & Study design and duration & Nitrate dose & Type of mouthwash & Measurement & $\begin{array}{l}\text { Significant } \\
\text { outcomes }\end{array}$ \\
\hline \multicolumn{7}{|c|}{ ACUTE STUDIES } \\
\hline $\begin{array}{l}\text { Mitsui et } \\
\text { al., } 2017^{75}\end{array}$ & $\begin{array}{l}\mathrm{n}=12(6 \mathrm{M} / 6 \mathrm{~F}) \\
\text { Normotensive, } \\
\text { Age } 19-44 \mathrm{y} \\
\text { Non-smoking, }\end{array}$ & $\begin{array}{l}\text { Acute, } \mathrm{RCT}, \mathrm{CO} \\
4 \text { visits } 10 \mathrm{~h} \text { in duration with } \\
1 \text { wk washout. } \\
\text { Saliva and oral bacteria } \\
\text { collected } 0,1 \text { and } 10 \mathrm{~h} .\end{array}$ & $\begin{array}{l}100 \mathrm{~g} \text { lettuce } \\
(110 \mathrm{mg} \mathrm{NO})_{3} \\
\text { with breakfast. } \\
\text { Lunch at } 5 \mathrm{~h} \text {. }\end{array}$ & $\begin{array}{l}\text { 1. Water (control) } \\
\text { 2. Listerine (antiseptic) } \\
\text { 3. Isodine (povidone- } \\
\text { iodine, } 0.35 \% \text { ) } \\
\text { 4. Chlorhexidine } \\
0.0025 \% \\
\text { Treatment for } 3 \text { min } \\
\text { prior to nitrate ingestion }\end{array}$ & Oral bacteria & $\begin{array}{l}\text { Relative to baseline: } \\
\uparrow \mathrm{NO}_{3} \text { and } \mathrm{NO}_{2} \\
\text { after each treatment } \\
\text { (P<0.05) } \\
\downarrow \text { nitrate reducing } \\
\text { bacterium } V . \text { Dispar } \\
\text { at } 1 \text { and } 5 \mathrm{~h} \text { after } \\
\text { Chlorhexidine }\end{array}$ \\
\hline \multirow[t]{2}{*}{$\begin{array}{l}\text { Govoni et } \\
\text { al } 2008^{27}\end{array}$} & \multirow{2}{*}{$\begin{array}{l}\mathrm{n}=7 \\
\text { Normotensive } \\
\text { Age } 24-51 \mathrm{y} \\
\text { BMI } 23 \mathrm{~kg} / \mathrm{m}^{2} \\
\text { Non-smoking }\end{array}$} & \multirow{2}{*}{$\begin{array}{l}\text { Acute, RCT, CO } \\
2 \text { visits of } 3 \mathrm{~h} \text { in duration. } \\
\text { Blood and saliva samples } \\
\text { collected before and for } 3 \mathrm{~h} \\
\text { after nitrate intake. } \\
\text { Oral bacteria collected in } \mathrm{n}=4 \\
\text { after mouthwash only. }\end{array}$} & \multirow[t]{2}{*}{$\begin{array}{l}10 \mathrm{mg} / \mathrm{kg} \\
\mathrm{NaNO}_{3} \text { in } 100 \\
\text { ml water }\end{array}$} & \multirow{2}{*}{$\begin{array}{l}\text { Mouthwash vs no } \\
\text { mouthwash } \\
\text { Corsodyl } \\
\text { (Chlorhexidine) gargled } \\
\text { twice for } 1 \text { min, } 15 \text { min } \\
\text { before nitrate ingestion. }\end{array}$} & Saliva & $\begin{array}{l}\uparrow \mathrm{NO}_{3} \text { on both visits } \\
\downarrow \mathrm{NO}_{2} \text { vs no } \\
\text { mouthwash }\end{array}$ \\
\hline & & & & & Oral bacteria & $\begin{array}{l}\mathrm{NO}_{3} \downarrow 29 \mathrm{nM} \text { and } \\
\mathrm{NO}_{2} \downarrow 250 \mathrm{nM} \text { at } 3 \\
\mathrm{~h} \text { vs no mouthwash } \\
\downarrow \text { bacteria count and } \\
(80 \%) \text { and nitrate } \\
\text { reducing capacity } \\
\text { after mouthwash. }\end{array}$ \\
\hline
\end{tabular}




\begin{tabular}{|c|c|c|c|c|c|c|}
\hline \multirow[t]{4}{*}{$\begin{array}{l}\text { Woessner } \\
\text { et al } 2016^{30}\end{array}$} & \multirow{4}{*}{$\begin{array}{l}\mathrm{n}=12(\mathrm{M}) \\
\text { Normotensive } \\
\bar{x} \text { age } 36 \mathrm{y} \text { and } \\
\text { BMI } 24 \mathrm{~kg} / \mathrm{m}^{2} \\
\text { Non-smoking }\end{array}$} & \multirow{4}{*}{$\begin{array}{l}\text { Acute, } \mathrm{RCT}, \mathrm{CO} \\
4 \text { visits, } 4 \mathrm{~h} \text { in duration with } \\
1 \mathrm{wk} \text { washout. } \\
\mathrm{BP} \text {, blood and saliva } \\
\text { collected before and for } 4 \mathrm{~h} \\
\text { after juice consumption }\end{array}$} & \multirow[t]{4}{*}{$\begin{array}{l}140 \mathrm{ml} \text { of } \\
\text { concentrated } \\
\text { beetroot juice } \\
(8.4 \text { mmol } \\
\text { nitrate })\end{array}$} & \multirow{4}{*}{$\begin{array}{l}\text { 1) Water (control) } \\
\text { 2) Listerine (antiseptic) } \\
\text { 3) Cepacol } \\
\text { (antibacterial) } \\
\text { 4) Chlorhexidine } \\
(0.12 \%) \\
\text { Treatment } 15 \text { min after } \\
\text { beetroot juice for } 60 \mathrm{~s} \text {. }\end{array}$} & SBP & $\begin{array}{l}\downarrow \text { Listerine and } \\
\text { control vs Cepacol } \\
\text { and Chlorhexidine } \\
(\mathrm{P} \leq 0.05)\end{array}$ \\
\hline & & & & & DBP & NS \\
\hline & & & & & Saliva & $\begin{array}{l}\uparrow \mathrm{NO}_{3} \text { all treatments } \\
\uparrow \mathrm{NO}_{2} \text { control vs all } \\
\text { mouthwashes and } \downarrow \\
\mathrm{NO}_{2} \text { Chlorhexidine } \\
\text { and Cepacol vs } \\
\text { antiseptic }(\mathrm{P} \leq 0.05)\end{array}$ \\
\hline & & & & & Plasma & $\begin{array}{l}\uparrow \mathrm{NO}_{3} \text { all } \\
\text { treatments } \\
\downarrow \mathrm{NO}_{2} \\
\text { Chlorhexidine vs all } \\
\text { treatments and } \\
\text { Cepacol vs control } \\
(\mathrm{P} \leq 0.05)\end{array}$ \\
\hline
\end{tabular}




\begin{tabular}{|c|c|c|c|c|c|c|}
\hline $\begin{array}{l}\text { Bondonno } \\
\text { et al } 2012^{76}\end{array}$ & $\begin{array}{l}\mathrm{N}=16 \mathrm{~F} \\
\text { Normotensive } \\
\bar{x} \text { age } 52 \pm 11 \mathrm{y} \\
\text { (F) } \\
\text { Non-smokers, }\end{array}$ & $\begin{array}{l}\text { Acute, } \mathrm{RCT}, \mathrm{CO} \\
5 \text { visits of } 3 \mathrm{~h} \text { in duration. } \\
1 \mathrm{wk} \text { washout. } \\
\text { Blood and saliva samples } \\
\text { collected before and for } 3 \mathrm{~h} \\
\text { after nitrate intake }\end{array}$ & $\begin{array}{l}0,100,200, \\
400 \mathrm{mg} \text { NaNO3 } \\
\text { in water }\end{array}$ & $\begin{array}{l}\text { 1) Antibacterial } \\
\text { toothpaste }(0.3 \% \\
\text { triclosan) } \\
\text { 2) } \\
\text { Toothpaste } \\
\text { without } \\
\text { antimicrobial } \\
\text { agent (control) }\end{array}$ & Plasma & $\uparrow \mathrm{NO}_{3}$ all treatments \\
\hline \multicolumn{7}{|c|}{ ACUTE WITHIN CHRONIC } \\
\hline $\begin{array}{l}\text { McDonagh } \\
\text { et al } 2016^{80}\end{array}$ & $\begin{array}{l}\mathrm{n}=12(6 \mathrm{M} / 6 \mathrm{~F}) \\
\text { Normotensive } \\
\bar{x} \text { age } 22 \pm 2 \mathrm{y}(\mathrm{F}) \\
\text { and } 24 \pm 2 \mathrm{y}(\mathrm{M}) . \\
\text { Non-smokers, }\end{array}$ & $\begin{array}{l}\text { Acute within chronic, RCT, } \\
\text { double blind } \\
6 \text { visits over } 8 \text { weeks } \\
\text { Each treatment } 6 \text { days, with } \\
\text { acute visits ( } 4 \text { h) on days } 0 \\
\text { and } 6 \text {. } \\
\text { Acute visits: Rinse with } \\
\text { mouthwash } 15 \text { min before } \\
\text { ingesting } 2 \text { x } 70 \text { ml beetroot } \\
\text { juice. Measurements at } 0,2 \\
\text { and } 4 \text { h. BP and PWA } \\
\text { measured at rest and during } \\
10 \text { min of treadmill walking. } \\
\text { Saliva and plasma samples } \\
\text { collected. }\end{array}$ & $\begin{array}{l}70 \mathrm{ml} \text { of } \\
\text { beetroot juice } \\
(6.2 \mathrm{mmol} \\
\text { nitrate }) \text { twice a } \\
\text { day }\end{array}$ & $\begin{array}{l}\text { 1) Strong - Corsodyl } \\
\text { (Chlorhexidine) } \\
\text { 2) Weak - Vademecum } \\
\text { med (non-chlorhexidine- } \\
\text { containing antibacterial } \\
\text { mouthwash) } \\
\text { 3) Deionised water (con) } \\
\text { 3X daily } 15 \text { mins before } \\
\text { beetroot juice and meals, } \\
\text { for } 6 \text { days }\end{array}$ & $\begin{array}{l}\text { DBP } \\
\text { MAP } \\
\text { HR } \\
\text { PWA }\end{array}$ & $\begin{array}{l}\text { Relative to baseline } \\
(0 \mathrm{~h}) \text { : } \\
\text { Resting - NS } \\
\text { After } 10 \text { min } \\
\text { exercise, } \uparrow 3 \mathrm{mmHg} \\
\text { after strong } \\
\text { mouthwash vs } \\
\text { control }(\mathrm{P}=0.07) 4 \\
\text { h after beetroot } \\
\text { juice } \\
\text { Resting and during } \\
\text { exercise - NS } \\
\text { Resting - NS } \\
\text { After } 10 \text { min } \\
\text { exercise, } \uparrow \text { after } \\
\text { strong mouthwash } \\
\text { vs control (P<0.05) } \\
\text { at } 4 \text { h. } \\
\text { During exercise } \uparrow \\
\text { after strong vs } \\
\text { control and weak } \\
\text { (P<0.05). } \\
\text { NS }\end{array}$ \\
\hline
\end{tabular}




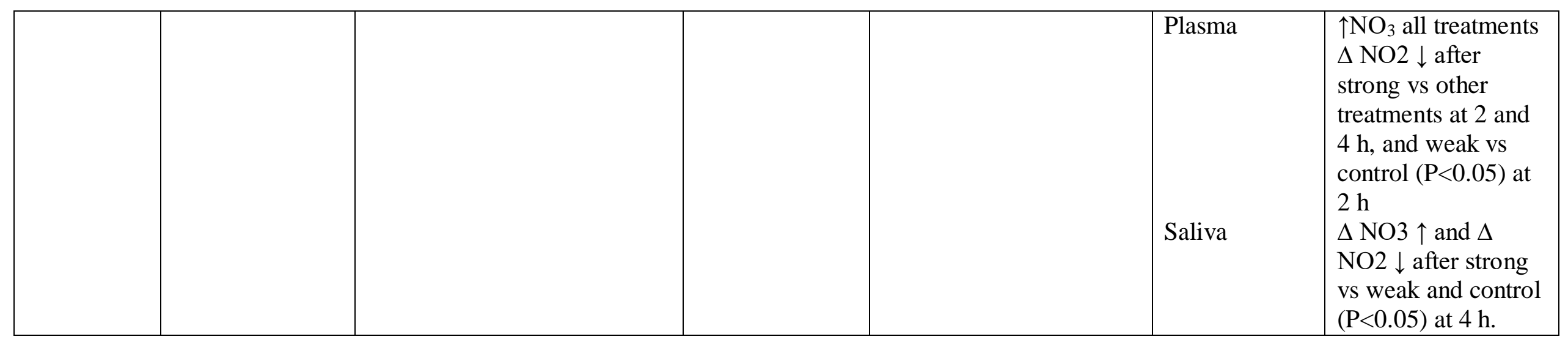

Abbreviations: DBP: Diastolic Blood Pressure, HR: Heart Rate, MAP: Mean Arterial Pressure, RCT: Randomized Controlled Trial, NS: Not

Significant, PWA: Pulse Wave Analysis, SBP: Systolic Blood Pressure, CO: Cross Over. 
Table 4: Chronic human studies investigating the involvement of oral bacteria in the blood pressure lowering effect of nitrate.

\begin{tabular}{|c|c|c|c|c|c|c|}
\hline Reference & $\begin{array}{l}\text { Subject } \\
\text { characteristics }\end{array}$ & $\begin{array}{l}\text { Study design and } \\
\text { duration }\end{array}$ & $\begin{array}{l}\text { Oral nitrate } \\
\text { reducing } \\
\text { capacity }\end{array}$ & Mouthwash regime & Measurement & $\begin{array}{l}\text { Significant outcome } \\
\text { between treatment }\end{array}$ \\
\hline $\begin{array}{l}\text { Tribble et } \\
\text { al., } 2019^{78}\end{array}$ & $\begin{array}{l}\mathrm{n}=26 \\
(16 \mathrm{~F} / 10 \mathrm{M}) \\
\text { Normotensive } \\
\text { Age } 22-71 \mathrm{y}\end{array}$ & $\begin{array}{l}\text { Sequential } \\
4 \text { visits over } 14 \text { days: } \\
\text { days } 1 \text { (baseline), } 7 \text { (post } \\
\text { mouth wash), } 10 \\
\text { (recovery) and } 14 \\
\text { (recovery) } \\
\text { Clinic BP and oral } \\
\text { bacteria at each visit. n=6 } \\
\text { oral nitrate reducing } \\
\text { capacity for } 8 \mathrm{~h} \text { after } 30 \mathrm{~s} \\
\text { mouthwash }\end{array}$ & $\begin{array}{l}\text { Mouth rinse } \\
\text { with } 1 \mathrm{mM} \\
\mathrm{NaNO}_{3} \text { for } 2 \\
\text { min }\end{array}$ & $\begin{array}{l}\text { Chlorhexidine }(0.12 \%) \\
2 x \text { daily for } 30 \mathrm{sec}\end{array}$ & $\begin{array}{l}\text { SBP } \\
\text { DBP } \\
\text { Oral bacteria }\end{array}$ & $\begin{array}{l}\text { In response to mouthwash, } \\
\uparrow 5 \mathrm{mmHg} \text { (n=9) and } \downarrow \\
\text { (n=4) } \\
\mathrm{NS} \\
\downarrow \text { Species diversity and } \\
\text { abundance with } \\
\text { mouthwash for } 7 \text { days. } \uparrow \\
\text { bacterial metabolic activity } \\
\text { at day } 14 \text {. } \\
\downarrow \mathrm{NO}_{3} \text { : } \mathrm{NO}_{2} \text { ratio for } 6-8 \mathrm{~h} \\
\text { after mouthwash. }\end{array}$ \\
\hline
\end{tabular}




\begin{tabular}{|c|c|c|c|c|c|c|}
\hline $\begin{array}{l}\text { Sunqvist et } \\
\text { al } 2016^{79}\end{array}$ & $\begin{array}{l}\mathrm{n}=17(\mathrm{~F}) \\
\text { Normotensive } \\
\bar{x} \text { age } 23 \mathrm{y} \\
\mathrm{BMI}=22 \\
\mathrm{~kg} / \mathrm{m}^{2} \\
\text { Non-smoking. }\end{array}$ & $\begin{array}{l}\text { RCT, CO, double blind } \\
\text { Each treatment } 3 \text { days } \\
\text { with a } 28 \text { day washout } \\
4 \text { visits (days } 3 \text { and } 4 \text { of } \\
\text { each treatment) } \\
24 \text { h ABP and urine } \\
\text { sample. } \\
\text { Clinic BP, saliva and } \\
\text { plasma samples and oral } \\
\text { nitrate reducing capacity }\end{array}$ & $\begin{array}{l}\text { Mouth rinse } \\
\text { with } 10 \mathrm{mM} \\
\mathrm{NaNO}_{3} \text { for } 5 \\
\text { min }\end{array}$ & $\begin{array}{l}\text { Chlorhexidine }(0.2 \%) \text { or } \\
\text { placebo mouthwash } \\
3 \text { x daily after meals for } \\
60 \mathrm{~s} \text {. }\end{array}$ & $\begin{array}{l}\text { Plasma } \\
\text { Urine } \\
\text { Oral nitrate } \\
\text { reducing } \\
\text { capacity }\end{array}$ & $\begin{array}{l}\uparrow \mathrm{NO}_{3} \text { and } \downarrow \mathrm{NO}_{2} \text { after } \\
\text { mouthwash }(\mathrm{P} \leq 0.01) \\
\text { No change in } \mathrm{NO}_{3} \text { and } \\
\mathrm{NO}_{2} \text { with mouthwash vs } \\
\text { placebo } \\
\text { excretion of } \mathrm{NO}_{3} \text { with } \\
\text { mouthwash vs placebo } \\
\downarrow \mathrm{NO} \text { after mouthwash (8 } \\
\mu \mathrm{M}) \text { vs placebo ( } 234 \\
\mu \mathrm{M})(\mathrm{P}<0.001)\end{array}$ \\
\hline $\begin{array}{l}\text { Bondonno } \\
\text { et al } 2015^{77}\end{array}$ & $\begin{array}{l}\mathrm{n}=15(8 \mathrm{M} / 7 \mathrm{~F}) \\
\text { Hypertensives } \\
\text { taking } \\
\text { medication }\end{array}$ & $\begin{array}{l}\text { RCT, CO } \\
\text { Each treatment } 3 \text { days } \\
\text { with a 10-12 day washout. }\end{array}$ & $\begin{array}{l}\text { Ratio of } \mathrm{NO}_{2} \\
\text { and } \mathrm{NO}_{3} \\
\text { measured in } \\
\text { saliva. }\end{array}$ & $\begin{array}{l}\text { Chlorhexidine or tap } \\
\text { water } \\
\text { (control) }\end{array}$ & DBP & $\begin{array}{l}\uparrow 2.3 \mathrm{mmHg} \text { after } \\
\text { mouthwash vs water }(\mathrm{P}= \\
0.01)\end{array}$ \\
\hline
\end{tabular}




\begin{tabular}{|c|c|c|c|c|c|c|}
\hline & $\begin{array}{l}\text { BP } 120- \\
159 / 100 \mathrm{mmHg} \text {. } \\
\text { Age } 53-69 \mathrm{y} \\
\text { and } \\
\text { BMI } 20-35 \\
\mathrm{~kg} / \mathrm{m}^{2} \text {. } \\
\text { Non-smokers }\end{array}$ & $\begin{array}{l}\text { Visits at day } 0 \text { and } 3 \text { of } \\
\text { each treatment. } \\
\text { Saliva sample, oral nitrate } \\
\text { reducing capacity and } \\
\text { plasma sample. BP } \\
\text { measured at home. }\end{array}$ & & $\begin{array}{l}2 \mathrm{x} \text { daily with } 20 \mathrm{ml} \text { for } \\
30 \mathrm{sec} \text { after brushing } \\
\text { teeth }\end{array}$ & $\begin{array}{l}\text { Plasma } \\
\text { Oral nitrate } \\
\text { reducing } \\
\text { capacity }\end{array}$ & $\begin{array}{l}\uparrow \mathrm{NO} 3 \text { and } \downarrow \mathrm{NO} 2 \text { after } \\
\text { mouthwash vs control (P= } \\
0.001) \\
\downarrow \mathrm{NO} 2 \text { after mouthwash vs } \\
\text { control }(\mathrm{P}=0.09) . \mathrm{NO}_{3} \text { - } \\
\mathrm{NS} \\
\downarrow \text { nitrate reductase ratio } \\
\text { after mouthwash }\end{array}$ \\
\hline $\begin{array}{l}\text { Kapil et al } \\
2013^{41}\end{array}$ & $\begin{array}{l}\mathrm{n}=19, \\
\text { Normotensive, } \\
\text { Age } 18-45 \mathrm{y}, \\
\text { BMI } 18-40 \\
\mathrm{~kg} / \mathrm{m}^{2} \text {, } \\
\text { Non-smokers, } \\
\text { No self- } \\
\text { reported use of }\end{array}$ & $\begin{array}{l}\text { At each visit, clinic BP, } \\
\text { blood, urine and saliva } \\
\text { samples and oral nitrate } \\
\text { reduction capacity. }\end{array}$ & $\begin{array}{l}\text { Mouth rinse } \\
\text { after holding } \\
3 \text { doses of } \\
\mathrm{KNO}_{3}(0,0.8 \\
\text { and } 80 \mu \mathrm{mol}) \\
\text { in the mouth } \\
\text { for } 5 \text { min. }\end{array}$ & $\begin{array}{l}\text { Chlorhexidine }(0.2 \%) \\
\text { 2x daily days } 8-14 \text { only. }\end{array}$ & $\begin{array}{l}\text { Clinic DBP } \\
\text { A-SBP } \\
\text { A-DBP } \\
\text { Home SBP } \\
\text { Home DBP } \\
\text { HR }\end{array}$ & $\begin{array}{l}\text { Relative to baseline, use of } \\
\text { mouthwash } \\
\uparrow 3.5 \mathrm{mmHg}(\mathrm{P}=0.003) \\
\uparrow 2.2 \mathrm{mmHg}(\mathrm{P}=0.038) \\
\uparrow 2.4 \mathrm{mmHg}(\mathrm{P}=0.017) \\
\uparrow 2.2 \mathrm{mmHg}(\mathrm{P}=0.014) \\
\uparrow 2.9 \mathrm{mmHg}(\mathrm{P}<0.001) \\
\uparrow 2.0 \mathrm{mmHg}(\mathrm{P}<0.001) \\
\mathrm{NS}\end{array}$ \\
\hline
\end{tabular}




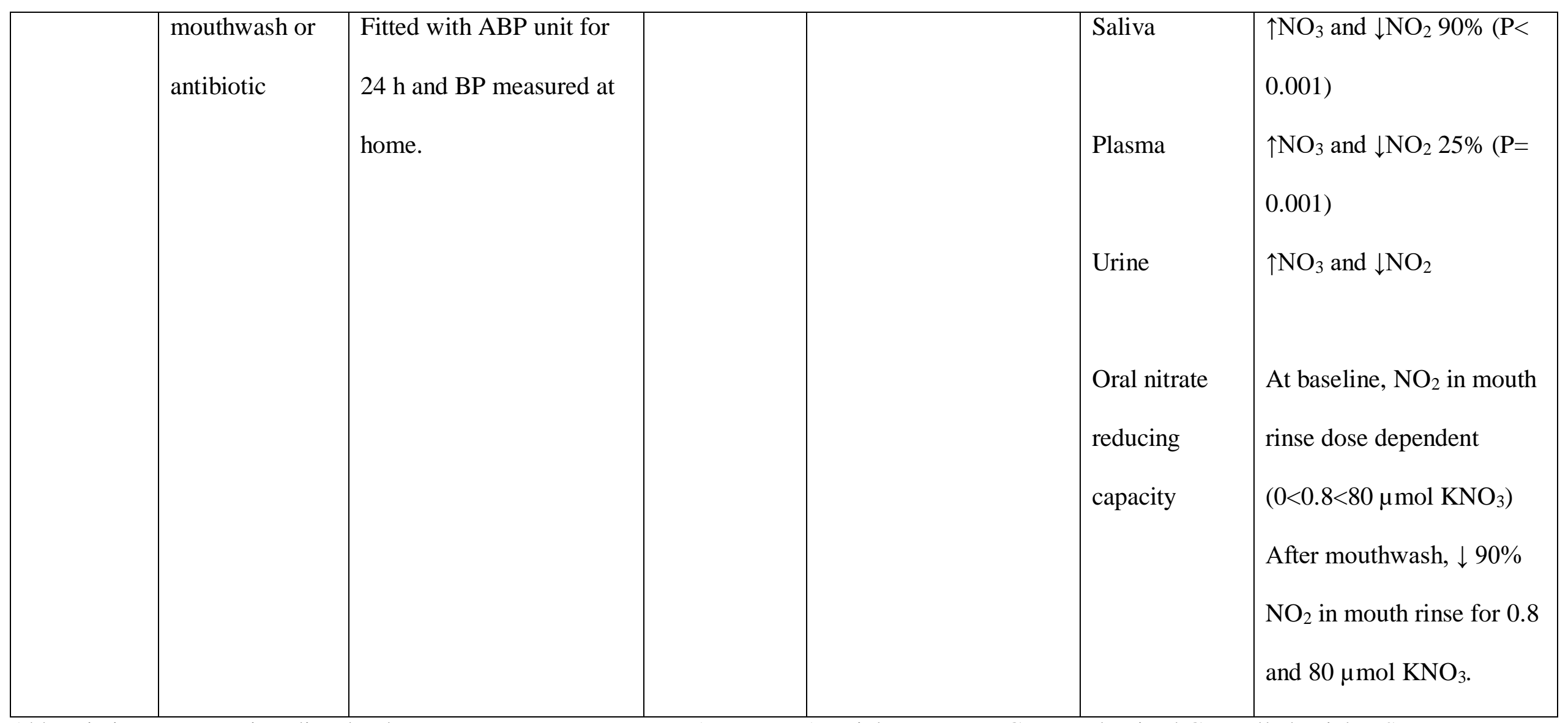

Abbreviations: DBP: Diastolic Blood Pressure, HR: Heart Rate, MAP: Mean Arterial Pressure, RCT: Randomized Controlled Trial, NS: Not

Significant, PWA: Pulse Wave Analysis, SBP: Systolic Blood Pressure, CO: Cross Over, ABP: Arterial Blood Pressure 


\section{FIGURE LEGENDS}

Figure 1: Diagram of the endogenous generation of nitric oxide (NO) by NO synthase (NOS) (right panel highlighted in pink), and exogenous generation of NO from the diet (left panel highlighted in blue $)^{28}$. In biological fluids, $\mathrm{NO}$ is oxidized to nitrite $\left(\mathrm{NO}_{2}\right)$ and nitrate $\left(\mathrm{NO}_{3}\right)$ (dashed arrows).

Figure 2: Overview of the nitrate enterosalivary circulation and nitrate metabolism in humans.

Ingested inorganic nitrate is converted to nitrite in the oral cavity by nitrate reducing bacteria with reduction to NO and nitrogen oxides occurring within the acidic environment of the stomach.

Remining nitrate and other nitrate components are then rapidly absorbed into the bloodstream via the small intestine. A large proportion of nitrate is then excreted by the kidneys into the urine, with up to $25 \%$ being recycled by the salivary glands and then concentrated in saliva.

Figure 3: Flow of information through the different phases of the literature review 
FIGURE 1

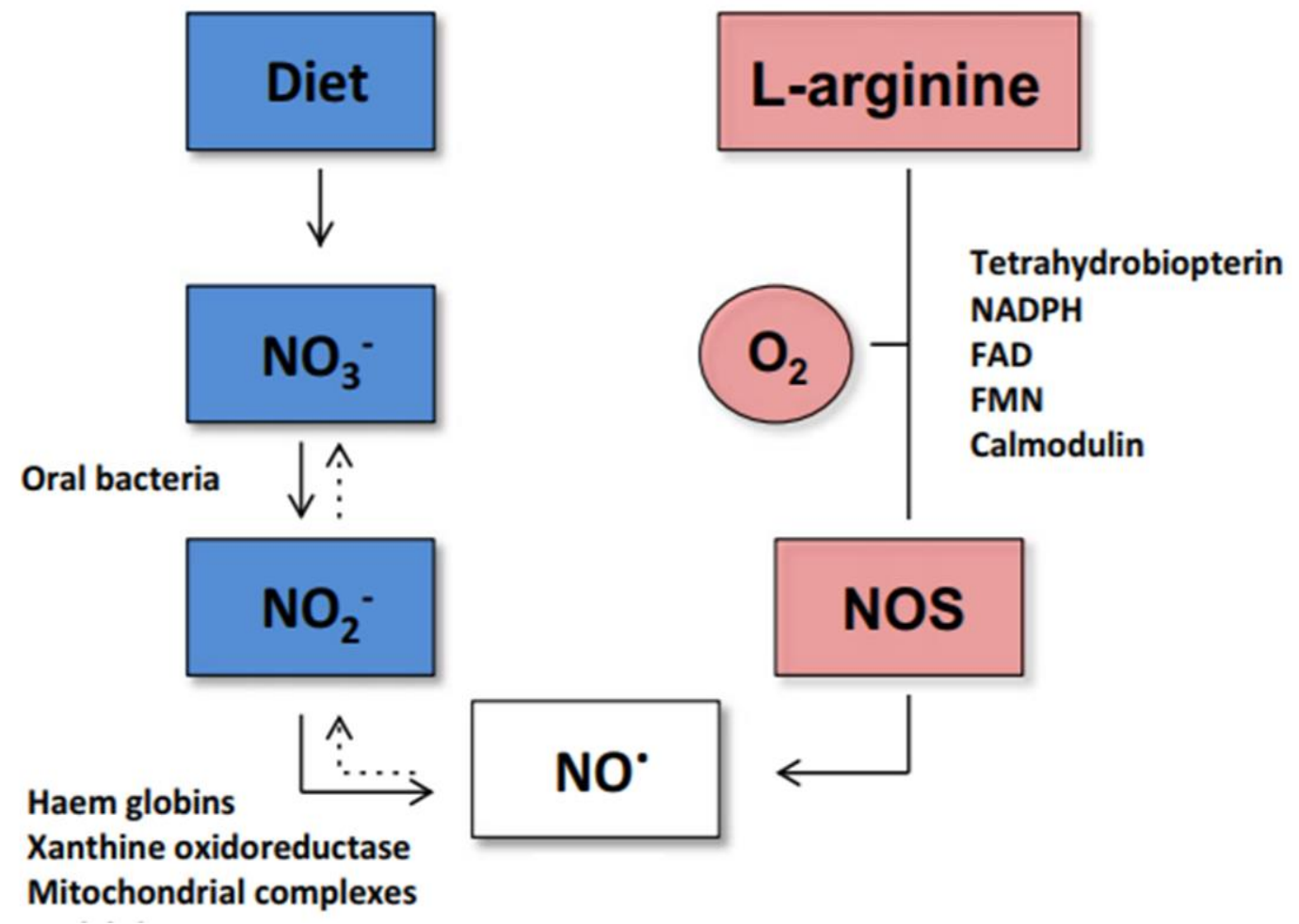




\section{FIGURE 2}

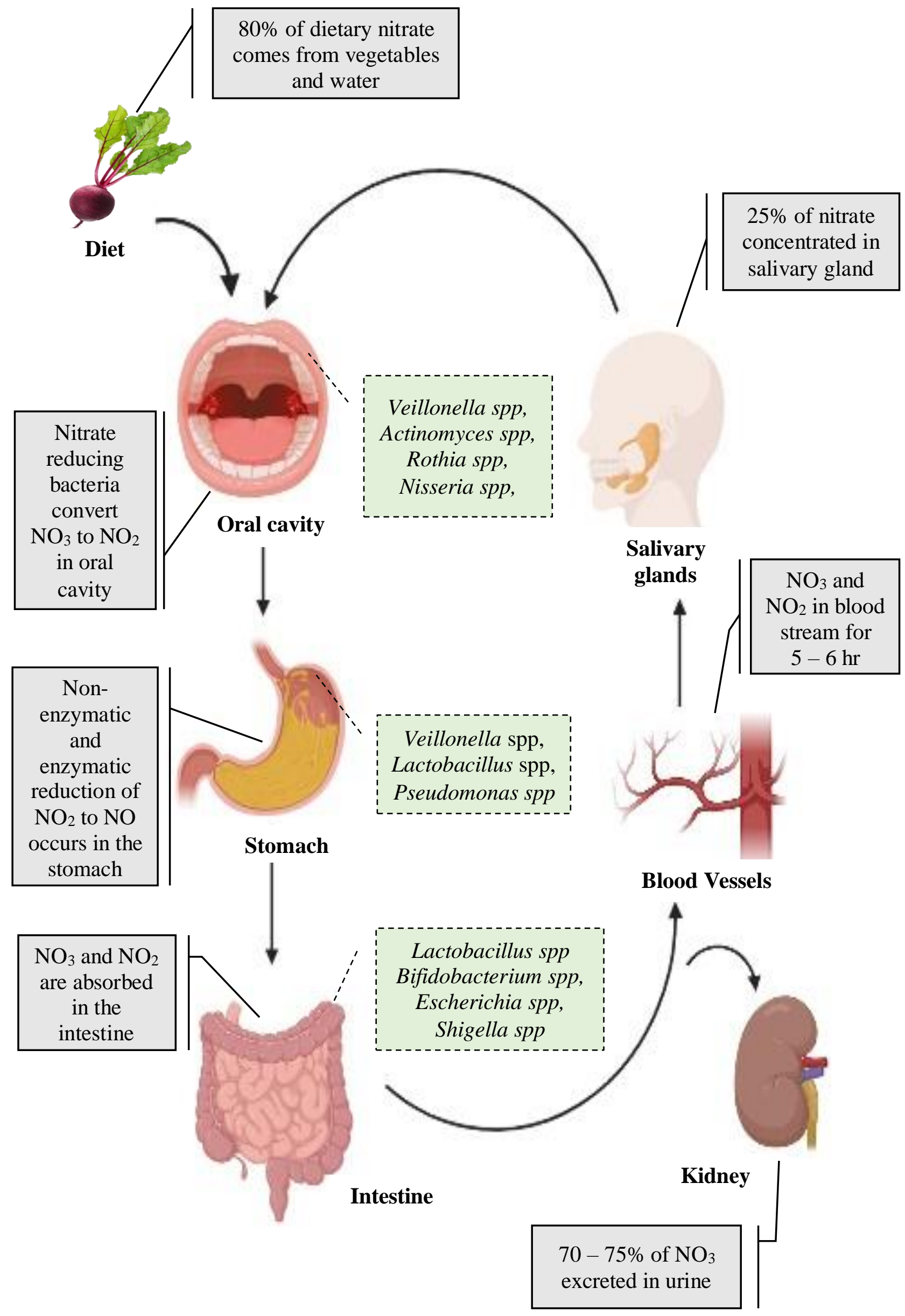




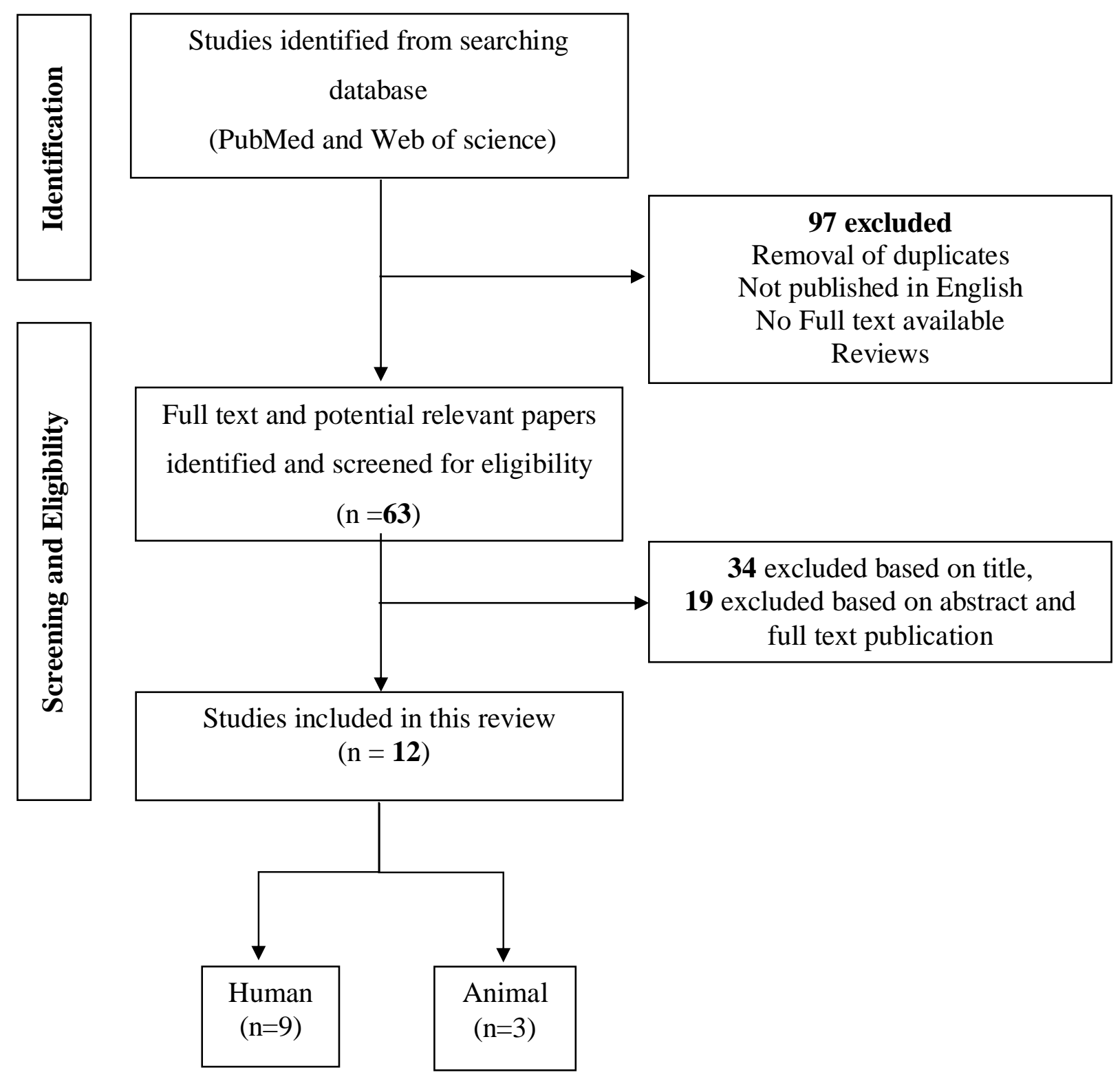

